\title{
HAZARDOUS WASTE CLASSIFICATION: REVIEW OF WORST CASE TO LESS WORST CASE METAL SPECIES WITH A WORKED EXAMPLE FOR A CONTAMINATED SOIL
}

\author{
Ian Bishop ${ }^{1, \star}$ and Pierre Hennebert ${ }^{2}$
}

${ }^{1}$ One Touch Data Ltd, Suite 4, Third Floor, Nicholsons House, Nicholsons Walk, Maidenhead SL6 1LD, United Kingdom

${ }^{2}$ INERIS (National Institute for Industrial Environment and Risks), BP 2, F-60550 Verneuil-en-Halatte, France

Article Info:

Received:

28 October 2020

Revised:

17 February 2021

Accepted:

25 February 2021

Available online:

31 March 2021

Keywords:

Hazardous properties

Worst case

Metal species

\begin{abstract}
The classification of waste as either hazardous or non-hazardous, especially for mixtures such as contaminated soils, ashes, filter cakes and sludges, is not straight forward. In particular, as the laboratories can only measure total metal concentrations, both the European and the UK technical guidance state that if the classifier doesn't know exactly which metal species is in their waste, then they should start from a worst case species and use lines of evidence to work towards a more reasonable (less hazardous) species. However, the guidance doesn't define or list worst case nor less worst case species. While some authors have documented worst case species, this is only in relation to documenting the concentrations at which each hazard property is triggered for a given worst case species. This paper addresses this gap. It documents how to define both the worst case species and more importantly, lists less worst case species for 32 elements and 204 metal species; species based on those listed in the European legislation but also supplemented by species that haven't (yet) been included in this legislation but are significant nevertheless. For each species, the paper tabulates the hazard property that triggers first, metal concentrations, conversion factors and other metadata, species by species, in descending order of hazard. Finally, to demonstrate how to use the data, either manually or by utilizing commercial software, the paper will give a worked example for a contaminated soil, showing how classifiers can use the list to help move from a worst case to a less worst case species.
\end{abstract}

\section{INTRODUCTION}

The classification of waste, in particular mixtures such as contaminated soils, ashes, filter cakes and sludges, as either hazardous or non-hazardous, is not a simple process. Whilst the European legislation allows two approaches, chemical testing and direct testing (also called effects-based testing or toxicity testing) (Concawe 2020), to assess the both the fifteen hazard properties and the persistent organic pollutants (POPs) content, neither is straight forward.

This paper reviews one of the biggest stumbling blocks for classifiers using the chemical testing approach, namely metal speciation. When a classifier asks a chemical test laboratory to characterize a particular waste, they will ask the laboratory to test their waste for a set of mainly heavy metals, for example, arsenic, cadmium, chromium, copper, lead, mercury, nickel, selenium and zinc. They will also ask for other determinands such as petroleum hydrocarbons, polyaromatic hydrocarbons (PAHs), selected anions, $\mathrm{pH}$ and moisture etc.; the actual selection being based on the findings of a desktop study. The challenge with the inorganic compounds is that a laboratory can only measure total metal concentrations (e.g. total zinc) while classification requires the use of metal compounds or species (e.g. zinc chromate) for hazardous waste classification. This is a different approach to the landfill legislation's simpler Waste Acceptance Criteria (WAC) defined in Council Decision 2003/33/EC, as amended (EU 2003), where the leaching concentration of twelve specific metals has to be less than a defined threshold for a particular class of landfill. For WAC, knowledge about the metal species is not required.

For a given metal, both the European Commission's and the UK's technical guidance (EU 2018, WM3 2018) state that where there is any doubt about which inorganic compounds are present, the classifier should start with worst case metal species and then work towards more reasonable case species, for a given metal, based on a combina- 
tion of lines of evidence and expert judgement. However, neither guidance document:

- lists worst case metal species, or

- lists other metal species in decreasing (less) worst case order.

As many workers still classify their waste by hand, or in spreadsheets, earlier papers (Hennebert 2019, INERIS, 2015) published tables detailing just the worst case species for a given metal (they use the term element), along with the relevant thresholds for each hazard property that applied to that metal species, under the regulations in place at the time the paper was written.

Utilising worst case species is fine especially if you are manually classifying your waste and a worst case outcome is acceptable. However, especially with the advent of comprehensive waste classification software that manages all the substances and the calculations, a manual approach leaves the classifier more likely to report a hazardous outcome, which increases transport and disposal costs and sends more waste to landfill. The manual approach also ignores the time savings, accuracy and reporting benefits of the on-line software.

This paper tabulates worst case to less worst case species for 32 elements and 204 metal species, covering commonly encountered alkali metals, alkaline earth metals, transition metals, metalloids and reactive non-metals from the periodic table. It also gives an example of how the classifier can work from worst case to a more reasonable case using lines of evidence and expert judgement.

\section{LEGISLATION}

Since the introduction of the Waste Framework Directive 2008/98/EC (EU 2008a) (WFD) and its enactment in each member state's national legislation, most domestic, commercial and industrial waste in Europe has to be classified as either hazardous or non-hazardous and given the appropriate six digit code from Decision 2014/955/EU (EU 2014a). This document is known both as the European Waste Catalogue (EWC) and the List of Waste (LoW). While many of the codes in the LoW are either absolute hazardous entries ( $\mathrm{AH}$, e.g. 030701 * fuel oil and diesel) or absolute non-hazardous entries (AN, e.g. 030101 waste bark and cork), codes applicable to many mixtures are called mirror entries. These entries are typically a pair of codes, one mirror hazardous $(\mathrm{MH})$, the other mirror non-hazardous (MN). For example, the mirror entries for a contaminated soil are:

- 1705 03* Soil and stones containing hazardous substances $(\mathrm{MH})$

- 170504 Soil and stones other than those mentioned in $170503 *(\mathrm{MN})$

The selection of which mirror entry code applies to the waste and goes on the disposal paperwork, depends on whether the waste has any hazardous properties or certain POPs.

A hazardous waste is a waste that due to its (intrinsic) chemical or other properties, displays one or more of the fifteen hazard properties listed in Annex III of the WFD or any of the POPs (above a given concentration limit or threshold) listed in EU (2014a). All the hazard properties and POPs are summarised in Table 1.

The WFD was amended further by Regulation (EU) No. $1357 / 2014$, known as the Annex III amendment (EU 2014b), and the later Regulation (EU) 2017/997 (EU 2017), known as the HP 14 amendment. These state that the classification of waste as hazardous is based on the European Union legislation for classifying chemicals; the current European chemical legislation being Regulation (EC) No. 1272/2008 for the Classification, Labelling and Packaging of substances and mixtures (EU 2008b), known as the CLP, and Regulation (EC) No 1907/2006 Registration, Evaluation, Authorisation and restriction of Chemicals (EU 2006), known as $\mathrm{REACH}$, plus some other subsidiary legislation covering cosmetics, pesticides, biocides and pharmaceuticals.

Annex VI, Table 3 of the CLP (CLP Table 3) contains more than 4,250 substances, known as harmonized entries. For each entry, it tabulates one or more hazard statements that together define which hazard properties are known to apply to that entry. These hazard statements, along with the thresholds and tests defined in both the Annex III amendment and the later HP 14 amendment, determine whether one or more substances in a waste, at given concentrations, a) makes the waste hazardous and b) for which hazard properties.

There are further challenges for classifiers (and technical publications, including this one), which can change the resultant classification.

1. CLP Table 3 is regularly updated by Adaptations to Technical and scientific Progress (ATPs). At the time of writing, there were 15 ATPs to the CLP. These, with respect to waste classification, can be divided into two general types; those that:

1.1.Modify CLP Table 3 by deleting existing harmonised entries, modifying the data for existing entries or adding new entries; typically these are published on an annual basis. ATP 1 (EU 2009) for example updated some 500 harmonised entries.

1.2. Change the rules, for example by adding a new hazard property, modifying calculation methods or defining new hazard statements. This type of ATP occurs every two years and is related to revisions of the United Nations' Global Harmonised System (GHS 2019). If the changes are waste related (as opposed to labelling or packaging of products for example), this would initiate a revised version of the technical guidance some months later.

2. The CLP, unlike the older European chemical legislation phased out in 2015 (EEC 1967, EU 1999) considers every entry in CLP Table 3 as potentially incomplete, i.e. a harmonized entry can be missing one or more hazard classes (e.g. carcinogenic, flammable liquid) and the classifier is meant to "self-classify" and identify any missing hazard classes. Whilst this is a challenge for the manufactures of chemical products, who know exactly which chemicals go into their products, it is much 
more of a challenge for waste classifiers dealing with mixtures, who potentially have to deal with many hundreds of (often unknown) compounds and tend not to have toxicologists or chemists on their staff.

\subsection{UK: Retained EU legislation}

Following the exit of the United Kingdom of Great Britain (GB) and Northern Ireland from the EU, the CLP Regulation as amended, is retained in UK law by the European Union (Withdrawal) Act 2018 (UK 2018) and subsequent exit regulations (UK 2019, 2020). All existing EU harmonised classification and labelling in force on 31 December 2020, are retained by the GB CLP Regulation in a data set known as the GB mandatory classification and labelling list or GB MCL list (UK 2020). Waste that is classified for disposal or recovery in $\mathrm{GB}$ is now required to use the mandatory entries in the GB MCL list, while waste classified for disposal or recovery in Northern Ireland (or rest of the EU) continues to use the harmonised entries in the EU CLP Regulation (EU 2008b). As the mandatory entries in the GB MCL list and the harmonised entries in CLP Table 3 are currently the same, this paper will just refer to the harmonised entries in CLP Table 3. In the future, while the entries in these two data sets may diverge slightly, the approach detailed in this paper can still be used to identify worst case and less worst case substances.

\section{TECHNICAL GUIDANCE}

Waste classification and with that an understanding of the European chemical legislation is daunting to most waste producers. Various national regulators have published varying levels of technical guidance over the last ten years, some as short as a couple of pages. Classifiers in the UK have had comprehensive, up-to-date, technical guidance throughout. The current version, WM3 v1.1 (WM3 2018), reflects the requirements of the most recent legislative changes, namely the HP 14 amendment.

Following publication of the HP 14 amendment in 2017, which came after a European Commission review of four different approaches for the calculation of HP 14 (Hennebert et al., 2016), the European Commission published the first Europe-wide technical guidance, Notice 2018/C 124 (EU 2018). Both WM3 (2018) and EU (2018) give a step by step (manual) approach to the whole waste classification process focusing on the chemical testing approach. The basic steps are:

Step 1. confirming the waste falls under the remit of the WFD (refer also to enacting national legislation),

Step 2. selecting the correct LoW code or mirror entry pair of LoW codes, and

Step 3. for mirror entries:

Step 3.1 identifying hazardous substances that may be or are in the waste,

Step 3.2 undertaking chemistry laboratory testing,

Step 3.3 assessing measured concentrations against a series of tests and thresholds,

Step 3.4 based on the outcome of Step 3.3, selecting the hazardous mirror entry code if the waste has one or more hazardous properties (or POPs); the non-hazardous mirror entry code if the waste does not have any hazardous properties (or POPs).

Both documents have a chapter for assessing each hazard property (and one for POPs), including flow diagrams and relevant calculations, plus guidance on finding data for either incomplete entries or for substances that are not in CLP Table 3. There are also chapters on assigning the correct LoW code(s) and an introduction to sampling and in WM3 (2018), a chapter on statistics.

While the two documents have exactly the same assessment methodologies for the assessment of the fifteen hazard properties and the POPs, there are a few differences between them. In particular:

Differences in the entry type designation $(\mathrm{AH}, \mathrm{AN}, \mathrm{MH}$, $\mathrm{MN}$ ) for 87 of the 843 LoW codes. For example, 0105 $05^{*}$ oil-containing drilling muds and wastes is $(\mathrm{MH})$ in EU (2018) and (AH) in WM3 (2018).

- Unlike WM3 (2018), EU (2018) offers no support for unknown oils (hydrocarbons) in a waste such as oil contamination in a soil, sludge or a filter cake. The reason is that terms like "unknown oil", "TPH" and "mineral oil" are not recognized as group entries in the CLP. However, classifiers still have to deal with unknown oil contamination in their wastes so WM3 (2018) provides a practical set of hazard statements to help classifiers assess unknown oils.

- WM3 (2018) also provides sets of hazard statements for a number of Petroleum Groups; specifically; petrol (gasoline), diesel, heavy fuel oils and crude oil. The commercial software, HazWasteOnline ${ }^{\mathrm{TM}}$ (www.hazwasteonline.com) has added two further Petroleum Groups for kerosene and bitumen. The creation of these Petroleum Groups is to aid the classifier in the assessment of oils, in particular oil contaminated mixtures such as soils, sludges and filter cakes. The reason for creating these Petroleum Groups is that the vast majority of the oils (specifically oils resulting from the refining of crude oil) in CLP Table 3 are incomplete; generally they only have a single hazard statement, typically for HP 7 carcinogenic, HP 11 mutagenic or HP 5 single target organ toxicity (STOT). This means that they are missing one or more hazard statements such as those for HP 14 ecotoxic or HP 3 flammable. It is worth noting that up until ATP 2 (2011), all the refined oils (and other entries such as coal tars) in CLP Table 3 were designated

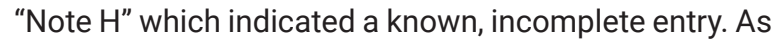
only a few of these oils have been updated since ATP 2 (2011), they remain incomplete. Therefore, classifiers should not use the entry in CLP Table 3 but should instead consult WM3 (2018) or REACH compliant Safety Data Sheets (SDS) from oil companies, to identify the missing hazard statements / hazard properties. A summary table of the hazard statement codes for different petroleum groups can also be found in Concawe (2020). 
It is outside the scope of this paper to describe the mathematical steps, the tests or rules, or the assignment of the different hazard properties when assessing a waste, as these, if classifying by hand, are clearly described in the guidance. If the classifier is using the commercial software, then all the data, tests, exceptions, notes and calculations are embedded in the classification engine, letting the classifier focus on what is in the waste, rather than how to do the calculations.

\section{HAZARD PROPERTIES}

The fifteen hazard properties and their hazard statements, along with the relevant cut-offs ${ }^{1}$, thresholds and whether the hazard statements are additive ${ }^{2}$ or individual ${ }^{3}$ are summarized in Table 1. The table also lists the POPs and their thresholds.

The hazard properties are split into three groups.

1. H200s; Physical hazards (HP 1 Explosive, HP 2 Oxidising and HP 3 Flammable and HP 15). Generally, the thresholds for these hazard statements can only be ascertained by physical testing. Table 1 references some of the physical tests which are detailed in the testing regulation (EC 2008c) and explained further in the European Chemical Agency's guidance to the application of the CLP (ECHA 2017). WM3 (2018) and EU (2018) do provide thresholds for some flammable substances that, in contact with water, may release flammable gases or which may ignite spontaneously (hazard codes $\mathrm{H} 260$ \& $\mathrm{H} 261$ )

2. H300s; Health hazards (HP 4 Irritant to HP 13 Sensitising)

3. H400s; Environmental hazards (HP 14 Ecotoxic)

Note that:

- the table contains additional hazard statements, defined in the CLP, that are not yet defined in the GHS; these are of the form EUH0xx, such as "EUH001 Explosive when dry" and are only included in a classification where another hazard property is present or if the guidance has defined a calculation method.

- for "HP 12 Release of an acute toxic gas", the technical guidance also details the methodology for calculating substance specific thresholds for substances assigned the following additional hazard statements: EUH029, EUH031 and EUH032.

TABLE 1: Summary of the fifteen hazard properties and POPS, their hazard statements and thresholds..

\begin{tabular}{|c|c|c|c|c|}
\hline $\begin{array}{l}\text { Hazard } \\
\text { Property }\end{array}$ & Hazard & $\begin{array}{l}\text { Hazard Statements } \\
\text { (code, class \& category) }\end{array}$ & $\begin{array}{l}\text { Cut- } \\
\text { offs }{ }^{1}\end{array}$ & Threshold ${ }^{2,3}$ \\
\hline \multicolumn{5}{|c|}{ Physical Hazards } \\
\hline HP 1 & Explosive & $\begin{array}{l}\mathrm{H} 200, \mathrm{H} 201, \mathrm{H} 2 \mathrm{O} 2, \mathrm{H} 2 \mathrm{O}, \mathrm{H} 204 \\
\mathrm{H} 240, \mathrm{H} 241\end{array}$ & - & Testing (mainly EU 2008c, A.14) or experience \\
\hline HP 2 & Oxidising & $\mathrm{H} 270, \mathrm{H} 271, \mathrm{H} 272$ & - & Testing (mainly EU 2008c, A.17) or experience \\
\hline HP 3 & Flammable & $\begin{array}{l}\mathrm{H} 220 \text { to } \mathrm{H} 226, \mathrm{H} 228, \mathrm{H} 240, \mathrm{H} 241 \\
\mathrm{H} 242, \mathrm{H} 250, \mathrm{H} 251, \mathrm{H} 252 \\
\mathrm{H} 260, \mathrm{H} 261\end{array}$ & - & $\begin{array}{l}\text { Testing (mainly EU 2008c, A.10) or experience } \\
\text { Examples of substance specific thresholds documented in WM3 } \\
(2018) \text {, Table C3.2, duplicated in EU (2018), Table } 11 .\end{array}$ \\
\hline \multicolumn{5}{|c|}{ Health Hazards } \\
\hline HP 4 & $\begin{array}{l}\text { Irritant } \\
\text { (Skin irritation and } \\
\text { eye damage) }\end{array}$ & $\begin{array}{l}\text { H314 Skin Corr. 1A } \\
\text { H318 Eye Dam. } 1 \\
\text { H315 Skin Irrit. } 2 \\
\text { H319 Eye Irrit. } 2\end{array}$ & $1 \%$ & $\begin{array}{l}\Sigma H 3141 \mathrm{~A} \geq 1 \% \\
\Sigma H 318 \geq 10 \% \\
\Sigma(H 315 \text { and } H 319) \geq 20 \%\end{array}$ \\
\hline HP 5 & $\begin{array}{l}\text { Specific Target Or- } \\
\text { gan Toxicity (STOT) } \\
\\
\text { Aspiration } \\
\text { Toxicity }\end{array}$ & $\begin{array}{l}\text { H370 STOT SE } 1 \\
\text { H371 STOT SE } 2 \\
\text { H335 STOT SE } 3 \\
\text { H372 STOT RE } 1 \\
\text { H373 STOT RE } 2 \\
\text { H304 Asp. Tox. } 1\end{array}$ & - & $\begin{array}{l}\text { Ind. } H 370 \geq 1 \% \\
\text { Ind. } H 371 \geq 10 \% \\
\text { Ind. } H 335 \geq 20 \% \\
\text { Ind. } H 372 \geq 1 \% \\
\text { Ind. } H 373 \geq 10 \% \\
\text { Ind. } H 304 \geq 10 \% \\
\sum \mathrm{H} 304 \geq 10 \% \text { and overall kinematic viscosity }\left(\text { at } 40^{\circ} \mathrm{C}\right) \text {, is less than } \\
20.5 \mathrm{~mm}^{2} / \mathrm{s}\end{array}$ \\
\hline HP 6 & Acute Toxicity & $\begin{array}{l}\text { H300 Acute Tox. } 1 \text { (Oral) } \\
\text { H300 Acute Tox. } 2 \text { (Oral } \\
\text { H301 Acute Tox. } 3 \text { (Oral) } \\
\text { H302 Acute Tox } 4 \text { (Oral) } \\
\text { H310 Acute Tox. } 1 \text { (Dermal) } \\
\text { H310 Acute Tox. } 2 \text { (Dermal) } \\
\text { H311 Acute Tox. } 3 \text { (Dermal) } \\
\text { H312 Acute Tox } 4 \text { (Dermal) } \\
\text { H330 Acute Tox } 1 \text { (Inhal.) } \\
\text { H330 Acute Tox. } 2 \text { (Inhal.) } \\
\text { H331 Acute Tox. } 3 \text { (Inhal.) } \\
\text { H332 Acute Tox. } 4 \text { (Inhal.) }\end{array}$ & $\begin{array}{c}\text { Cat. 1, } \\
2 \text { or 3: } \\
0.1 \% \\
\text { Cat. } 4: \\
1 \%\end{array}$ & $\begin{array}{l}\Sigma \mathrm{H} 3001 \geq 0.1 \% \\
\Sigma \mathrm{H} 3002 \geq 0.25 \% \\
\Sigma \mathrm{H} 301 \geq 5 \% \\
\Sigma \mathrm{H} 302 \geq 25 \% \\
\Sigma \mathrm{H} 3101 \geq 0.25 \% \\
\Sigma \mathrm{H} 3102 \geq 2.5 \% \\
\Sigma \mathrm{H} 311 \geq 15 \% \\
\Sigma \mathrm{H} 312 \geq 55 \% \\
\Sigma \mathrm{H} 3301 \geq 0.1 \% \\
\Sigma \mathrm{H} 3302 \geq 0.5 \% \\
\Sigma \mathrm{H} 331 \geq 3.5 \% \\
\Sigma \mathrm{H} 332 \geq 22.5 \%\end{array}$ \\
\hline HP 7 & Carcinogenic & $\begin{array}{l}\text { H350 Carc. 1A, 1B } \\
\text { H351 Carc. } 2\end{array}$ & - & $\begin{array}{l}\text { Ind. } \mathrm{H} 350 \geq 0.1 \% \\
\text { Ind. } \mathrm{H} 351 \geq 1 \%\end{array}$ \\
\hline HP 8 & Corrosive & H314 Skin Corr. 1A, 1B, 1C & $1 \%$ & $\Sigma H 314 \geq 5 \%$ \\
\hline HP 9 & Infectious & - & - & $\begin{array}{l}\text { Rules laid down in reference documents or legislation in Member } \\
\text { States - WM3 (2018), Appendix C9, EU (2018), Section } 3.9\end{array}$ \\
\hline HP 10 & $\begin{array}{l}\text { Toxic for reproduc- } \\
\text { tion }\end{array}$ & $\begin{array}{l}\text { H360 Repr. 1A, 1B } \\
\text { H361 Repr. } 2\end{array}$ & - & $\begin{array}{l}\text { Ind. } \mathrm{H} 360 \geq 0.3 \% \\
\text { Ind. } \mathrm{H} 361 \geq 3 \%\end{array}$ \\
\hline HP 11 & Mutagenic & $\begin{array}{l}\text { H340 Muta. 1A, 1B } \\
\text { H341 Muta. } 2\end{array}$ & - & $\begin{array}{l}\text { Ind. } \mathrm{H} 340 \geq 0.1 \% \\
\text { Ind. } \mathrm{H} 341 \geq 1 \%\end{array}$ \\
\hline
\end{tabular}




\begin{tabular}{|c|c|c|c|c|}
\hline HP 12 & $\begin{array}{l}\text { Release of an acute } \\
\text { toxic gas }\end{array}$ & EUH029, EUH031, EUH032 & - & $\begin{array}{l}\text { Testing (ECHA } 2017 \text { section } 2.12 \text { or } 1 \mathrm{M} \mathrm{HCl} \text { for EUH031 or } \\
\text { EUH032) or experience } \\
\text { Examples of substance specific thresholds documented in WM3 } \\
(2018) \text {, Table C12.2, duplicated in EU (2018), Table } 21\end{array}$ \\
\hline HP 13 & Sensitising & $\begin{array}{l}\text { H317 Skin Sens. 1, 1A, 1B } \\
\text { H334 Resp. Sens. 1, 1A, 1B }\end{array}$ & - & $\begin{array}{l}\text { Ind. } \mathrm{H} 317 \geq 10 \% \\
\text { Ind. } \mathrm{H} 334 \geq 10 \%\end{array}$ \\
\hline \multicolumn{5}{|c|}{ Environmental Hazards } \\
\hline HP 14 & Ecotoxic & $\begin{array}{l}\text { H400 Aquatic Acute } 1 \\
\text { H410 Aquatic Chronic } 1 \\
\text { H411 Aquatic Chronic } 2 \\
\text { H412 Aquatic Chronic } 3 \\
\text { H413 Aquatic Chronic } 4 \\
\text { H420 Ozone }\end{array}$ & $\begin{array}{l}\mathrm{H} 400 \text {, } \\
\mathrm{H} 410 \text { : } \\
0.1 \% \\
\mathrm{H} 411 \\
\mathrm{H} 412 \\
\mathrm{H} 413 \text { : } \\
1 \%\end{array}$ & $\begin{array}{l}\Sigma \mathrm{H} 400 \geq 25 \% \\
\sum[(100 * \mathrm{H} 410)+(10 * \mathrm{H} 411)+(\mathrm{H} 412)] \geq 25 \% \\
\sum(\mathrm{H} 410+\mathrm{H} 411+\mathrm{H} 412+\mathrm{H} 413) \geq 25 \% \\
\Sigma \mathrm{H} 420 \geq 0.1 \% \\
\text { Alternative: Direct Testing }\end{array}$ \\
\hline \multicolumn{5}{|c|}{ Physical, Health and Environmental Hazards } \\
\hline HP15 & $\begin{array}{l}\text { Waste capable of } \\
\text { exhibiting a hazard- } \\
\text { ous property not } \\
\text { displayed by the } \\
\text { original waste }\end{array}$ & $\begin{array}{l}\text { H205 Expl. } 1.5 \\
\text { EUH001; EUH019, EUH044 }\end{array}$ & - & $\begin{array}{l}\text { Testing, (ECHA } 2017 \text { section } 2.1 \text { provides guidance on EUH001, } \\
\text { EUH044 and H205) or experience } \\
\text { Norden (2015) reports hazard property is not generally applied; } \\
\text { limits can be defined by individual member states }\end{array}$ \\
\hline \multicolumn{5}{|c|}{ Health and Environmental hazards } \\
\hline $\begin{array}{l}\text { Persistent } \\
\text { Organic } \\
\text { Pollutants } \\
\text { (POPs) }\end{array}$ & $\begin{array}{l}\text { Waste containing } \\
\text { one or more POPS; } \\
\text { the POPs being } \\
\text { those listed in EU } \\
\text { (2014a), thresh- } \\
\text { olds defined in EU } \\
\text { (2014c) }\end{array}$ & $\begin{array}{l}\text { Polychlorinated dibenzo-p-dioxins } \\
\text { and dibenzofurans (PCDD/PCDF); } \\
\text { Polychlorobiphenyls (PCBs) } \\
\text { Pesticides: } \\
\text { DDT; chlordane; dieldrin; endrin } \\
\text { hexachlorocyclohexanes, including } \\
\text { lindane; heptachlor; chlordecone; } \\
\text { hexachlorobenzene; aldrin; penta- } \\
\text { chlorobenzene; mirex; toxaphene } \\
\text { Brominated flame retardants: hex- } \\
\text { abromobiphenyl }\end{array}$ & - & $\begin{array}{l}\text { PCDD/PCDF: } \Sigma\left(C_{i} \times T E F_{i}\right) \geq 15 \mu \mathrm{g} / \mathrm{kg} \text { (where } \mathrm{TEF}_{\mathrm{i}} \text { is the toxic } \\
\text { equivalency factor and } \mathrm{C}_{\mathrm{i}} \text { the concentration of an individual PCDD } \\
\text { or PCDF substance } \mathrm{i} \text { ) } \\
\text { Rest: } \geq 50 \mathrm{mg} / \mathrm{kg}\end{array}$ \\
\hline \multicolumn{5}{|c|}{$\begin{array}{l}\text { Note : Annex IV of Regulation No. 850/2004 as amended (EU 2004) contains a larger list of POPs that have specific disposal requirements when found in } \\
\text { a waste: }\end{array}$} \\
\hline \multicolumn{5}{|c|}{$\begin{array}{l}\text { - Pesticides: endosulfan, dicofol (candidate POP) } \\
\text { - Brominated flame retardants: tetra-, penta-, hexa-, hepta- and decabromodiphenylether; hexabromocyclododecane (HBCDD) } \\
\text { - Chlorinated compounds: polychlorinated naphthalene; short-chain chlorinated paraffins (SCCPs); hexachlorobutadiene } \\
\text { - Fluorinated compounds: perfluorooctane sulfonic acid and its derivatives (PFOS); perfluorooctanoic acid (PFAS) and perfluorohexane sulfonic acid } \\
\text { (PFHxS) and their derivatives (candidate POPs) }\end{array}$} \\
\hline \multicolumn{5}{|c|}{ These POPs are not listed in the current waste regulations so do not make the waste hazardous at the threshold concentration of $50 \mathrm{mg} / \mathrm{kg}$. } \\
\hline
\end{tabular}

\section{WASTE CLASSIFICATION METHODOLOGY}

Assuming that the correct chemistry data have been collected for the classification step (Hennebert et al. 2013, AFNOR XP X30-489 2013), some practitioners (Hennebert 2019, INERIS 2015, Norden 2016) discuss a tiered approach to assessing whether the waste, in particular mixtures, has any hazardous properties. The approach is essentially a manual methodology, aimed at paper or spreadsheet based assessment:

- Tier 1: is confirming that the material is a waste and identifying the correct LoW code for absolute entries $(\mathrm{AH}, \mathrm{AN})$ or pair of codes $(\mathrm{MH}, \mathrm{MN})$ for mirror entries.

For the assessment of hazardous properties:

- Tier 2: Screening at high level to exclude non-relevant hazardous properties from further assessment. For example, it is likely that HP 1 Explosive, HP 2 Oxidising, HP 3 Flammable 4 , HP 9 Infectious can all be excluded for incinerator bottom ash (IBA) or fly ash, based partly on the nature of feed stock but also because the minimum incinerator temperature is $850^{\circ} \mathrm{C}$.

- Tier 3 a: Assessment of hazardous properties not eliminated in Tier 2 by determining the chemical composition of the waste.

- Tier 3 b: It may be necessary to undertake physical te- sting for some hazard properties not eliminated in earlier tiers. This step is mainly relevant for HP 1, HP 2 and HP 3. Note that HP 9 Infectious, which isn't assessed using the chemical analysis approach, also needs to be considered and either discounted at the desktop study stage or, other suitable (non-chemical) testing undertaken. Weight of evidence and expert judgement are often used in this step of the assessment.

- Tier 3 c: For some wastes it may be possible to assess hazardous properties based on the principle of bridging; assuming that the waste has the same LoW code as the waste from another process and is similar or identical to waste generated from that process. For example, in the UK, incinerator bottom ash (IBA) from the incineration or pyrolysis of municipal waste (19 01 $11 *$ / 1901 12) is generally disposed of under 190112 based on the ESA sampling and testing protocol (ESA, 2018) but bottom ash from the co-incineration of waste wood (10 01 14* / 1001 15) cannot use, or bridge using this protocol and the earlier findings of ESA's original baseline characterisation.

- Tier 4: for some waste streams, based on a positive, cost benefit analysis, more specialized chemical analysis and modelling may be advisable. For example, this might be considered for IBA from a waste wood co-incinerator that generates 10,000 tonnes of IBA every year. 
The rest of this paper will focus primarily on the Tier $3 a$ step and assessing metal species.

\subsection{Classification of Safety Data Sheets}

The classifier can use the information in a product's SDS when the product remains un-altered in the resulting waste stream. The use of the data in a SDS for waste classification can generate a different classification to the original product classification. Some hazardous products are re-classified as non-hazardous wastes and vice-a-versa. In particular, HP 4, HP 6, HP 8, HP 13 and HP 14 show major differences to their counterparts in the CLP regulation (INERIS 2016). The biggest discrepancies are caused by:

- In the case of products, classifiers have to use the Specific Concentration Limits and $\mathrm{M}$ factors ${ }^{5}$ where stated in Table 3 of the CLP, whereas their use is not required in waste classification.

- Any hazard statements published in Section 2 of the SDS can reflect additive calculations; calculations based on the actual concentrations of the ingredients in the mixture (Section 3); these additive calculations and hence the result, differ from those calculations utilized in waste classification.

- In Section 3 of the SDS, manufacturers disguise the exact composition of hazardous ingredients in their products by using ranges of concentrations (e.g. 5 to $10 \%$ ) or maximum concentrations (e.g. $<10 \%$ ); the waste classifier has to use the maximum concentrations.

\section{WASTE CLASSIFICATION}

Some of the most difficult wastes to characterize and classify are mixtures such as contaminated soils, filter cakes, ashes and sludges. This is because the classifier does not know exactly what is in the waste, combined with the knowledge that the standard laboratory test suites can't tell us everything we would like to know about the chemical composition of our particular waste.

For waste characterisation, many classifiers have a "minimum" chemical test suite that they will use as a starting point. With respect to the metals and considering waste soils, this minimum suite often includes antimony, arsenic, cadmium, chromium, copper, lead, mercury, nickel, selenium and zinc. Following a review of the processes that created and/or contaminated the waste, the classifier may then add extra metals to their minimum suite to better characterize the waste.

As an example, during work to determine whether a filter cake generated during the production of a firefighting foam has any hazardous properties (Bishop and Gill 2018), both calcium and iron were added to the suite of tests. The metals were identified because this industrial process entails the alkaline hydrolysis of a hoof and horn meal to release polypeptides. The process uses significant quantities of lime (calcium hydroxide, $\mathrm{CaO}$ ) to create the alkaline conditions and iron(II) sulphate $\left(\mathrm{FeSO}_{4}\right)$ and carbon dioxide $\left(\mathrm{CO}_{2}\right)$ after the hydrolysis. These metals were included, not because the resulting calcium and iron compounds in the filter cake were likely to be hazardous, but more to confirm that a) the hydrolysis and hence the filter cake contained what was expected and $b$ ) would help demonstrate a better mass balance calculation.

This requirement to identify all compounds that may be at sufficient concentration to trigger a hazardous property is in contrast to the WAC approach (EU 2003), where (with respect to inorganic compounds):

- WAC only requires the testing of the eluate for twelve specific metals (and three anions); these are therefore not total metal concentrations but only the soluble (leachable) metal fraction (WAC testing ignores the insoluble compounds), and

- Depending on the class of landfill (hazardous, inert etc.) the WAC assessment simply compares the concentrations against a defined concentration threshold; a simple pass fail approach.

A few actors offer a simple, spreadsheet-based, worst case type classification for contaminated soils whereby they undertake a "no extra knowledge" classification; to put it simply, they assume worst case substances for the metals and simply process the chemical analysis as is. However, there is much confusion over what is worst case, with a number of these actors incorrectly assuming that the compounds in the contaminated soil example in WM3 (2018) are worst case, which is incorrect; these compounds were chosen for a specific industrial contamination scenario and five of the seven quoted species are not worst case.

\subsection{Metal species}

The challenge is that the laboratory results for the metals only give you the total metal concentrations and not the specific species (or species ${ }^{6}$ ) concentrations for each metal. This species knowledge is critical in waste classification because:

- for each metal, we have to use the concentration of a metal species in a classification, not the total metal concentration (There are exceptions known as Note 1 compounds that are discussed later), and

- the standard laboratory tests can only estimate the total concentrations of individual metals e.g. total arsenic, copper or zinc and are not able to identify which specific species of metal is present in the waste.

There is a complementary technique, X-Ray Diffraction (XRD) (alongside X-Ray Fluorescence (XRF)), that can be used to analyse the mineral composition of naturally existing or manufactured crystalline materials. Unfortunately, XRD cannot identify compounds in complicated mixtures such as a soil where there are hundreds of amorphous compounds, with no crystalline form, disseminated throughout the material, typically with concentrations < $1 \%$.

The guidance states that where the classifier doesn't know which metal species is present in a waste, the classifier must start with the worst case and then work towards a more reasonable case, based on lines of evidence. The evidence that can be considered will depend on the nature of the waste stream and knowledge of some basic chemistry. 
For example, to assess an industrial filter cake, a desktop study would include:

- a review of the entire process that generates the filter cake; what are the input materials, which chemicals are added, what is the composition of the product and what substances might be expected in the filter cake based on the design of the process,

- examining what could be added by accident to the process due for example to equipment malfunction or contamination of the feed stock,

collecting REACH compliant SDS for chemicals utilised, understanding the chemical reactions - how substance $X$ reacts with substance $Y$ to create substance $Z$, and

- a review of any existing chemical data; data typically collected for a different purpose such as assays or the annual monitoring specified in an environmental permit.

For a contaminated soil, this desktop study would include:

- a review of the historical industrial uses of the site and surrounds - this would have been covered in a Phase 1 desktop type study,

- a review of any Phase 2 site investigation work, including the re-assessment of any chemical data gathered during that investigation to identify contaminated soils,

- a walk over to identify evidence of contamination such as burning, staining and fly tipping and any relevant issues that may have occurred post the site investigation, review of the construction drawings and materials management plan to identify a) where excavated soils would come from and b) what volume of soils are planned for disposal?

Following the review, the classifier would have also:

- designed the laboratory testing suite,

- including expanding the chemical analysis to help identify / rule out certain metal species and the type(s) of hydrocarbon contamination.

designed the sampling plan,

collected the samples, and

commissioned a suitable chemical test laboratory.

\subsection{Worst case}

WM3 (2018) introduces the term "Worst case substance" (Step 4, page 7) following an introduction stating that chemical analysis, with respect to mainly inorganic substances, does not always identify specific components but rather the individual cations (i.e. the metals) and anions (e.g. sulphates, phosphates, chlorides etc.). It makes it clear that if there is any doubt about which substance is in a waste, then "the worst case substance should be considered present". This term is further explained in Step 5 (page 8) which tells the classifier that they have to identify the 'worst case' substances, giving only lead chromate as an example for lead. The guidance then states that these worst case substances have to be identified separately for each hazard property.

EU (2018) uses the term "Realistic worst case substance" (section 4.2.1) and states that "Worse case com- pounds should be determined taking into consideration which substances reasonably could exist in the waste (e.g. based on the substances used in the process generating the waste and its associated chemistry)". It has a footnote to further define the term "reasonable" and defers to the definition in WM3 (2018) which states that "reasonable indicates that the substances cannot exist within the waste because, for example, of their physical and chemical properties can be excluded". The footnote does go further and refers readers to the INERIS (2015) technical guidance document which "contains a collection of 'realistic worst case' substances by elements for each hazard property".

This is as far as the guidance documents go as neither WM3 (2018) or EU (2018) reference or publish a list of either worst case compounds, or less worst case compounds, nor describe how to deal with some of the exceptions encountered when trying to compile such lists. Some authors (INERIS 2015) have published lists of worst case compounds, by element and hazard property, or have proposed a "worst case with information" list (Hennebert 2019) but none have published a comprehensive list of less worst case compounds focusing on compounds, rather than just hazard properties. This is partly because these approaches assume a manual analysis, which if you were to add more variables, such as less worst case, makes the classification process even more onerous.

The alternative approach to the manual, step by step identification of hazard properties for every substance in a waste, is to start with worst case species for all relevant metals (and all the other determinands such as the PAHs, hydrocarbons, $\mathrm{pH}$, moisture etc.), import the chemical results directly from the laboratory and classify using commercial software like HazWasteOnline ${ }^{\mathrm{TM}}$. This tells the classifier in seconds whether any of the determinands have any hazardous properties. If one or more determinands flag up as hazardous, the classifier can prioritise these for further work. If nothing flags up as hazardous, the classifier could stop at this point.

Typically most classifiers want to fine tune their classification further, either based on additional (analytical) knowledge of some of the inorganic compounds in the waste and/or because of other information in the chemical results which can help rule out certain inorganic compounds. For example, if there isn't any chromium(VI) in the waste (EN 15192), all the metal chromates can be swapped to the next (less) worst case species. However, the question then raised is what is the next less worst case metal species. Classifiers need a list that:

goes from worst case to less worst case for each metal, documents the metadata that first triggers a hazard property for each metal species, and

- details the assumptions and limitations used to compile the list.

It must be noted that both approaches, manual or software, still requires a thorough desktop study to both identify what to physically test for and for the metals, evidence for using more reasonable (less worst case) metal species. Both methods rely on the premise that the classifier 
has identified all potentially hazardous compounds in the waste.

\subsection{Conversion Factors, Group Entries and Note 1}

For a given metal, once the classifier has identified the metal species that they want to use, they have to perform one further step; converting the total metal concentration to the species concentration using a Conversion Factor (see note ${ }^{8}$ for worked example). The resulting species concentration is the number that has to be used in the waste classification.

There is one special case and one exception to this requirement: Group Entries and Note 1 entries.

- Group Entries (see Table 3 for examples) are of the form "metal $X$ compounds with the exception of those specified elsewhere in this Annex", the Annex being CLP Table 3 . So as long as the metal $X$ compound you suspect is in your waste (e.g. lead sulphate) is not listed in CLP Table 3, the classifier can use the metal's Group Entry instead. However, the classifier still has to apply a Conversion Factor for a hypothetical species; a species not already listed in CLP Table 3.

- Some entries in CLP Table 3 are marked as Note 1. The CLP's definition of Note 1 is "The concentration stated or, in the absence of such concentrations, the generic concentrations of this Regulation are the percentages by weight of the metallic element calculated with reference to the total weight of the mixture"; effectively this means that the classifier can use the total metal concentration in the classification and not worry about applying a Conversion Factor for a hypothetical metal species.

About half of the Group Entries in CLP Table 3 (e.g. lead compounds) are also Note 1 ; this simplifies the exercise even further as for these entries, the classifier doesn't have to work out a Conversion Factor for any particular metal species. However, for those Group Entries that are not Note 1 ; beryllium, chromium( $\mathrm{VI})$, selenium, thallium and uranium, the classifier has to utilise a Conversion Factor for a suitable metal compound and herein lies the challenge. There is no guidance or legislation that dictates how such a compound should be chosen and thus a suitable Conversion Factor defined. One practice is to go worst case and try and identify a worst case metal compound that is 1) not already listed in CLP Table 3 and 2) could be a reasonable source of contamination in the waste. Hennebert (2019) suggested the metal oxide where the oxide was not already a harmonised entry in CLP Table 3.

Apart from Group Entry "arsenic acid and its salts..." where arsenic acid is a logical selection, this paper utilises oxides for the Group Entries for selenium, thallium and uranium (plus an alternative chromate for thallium). However, where the oxides are present, both beryllium chloride and beryllium hydroxide and chromic acid ( $\mathrm{H} 2 \mathrm{CrO} 4)$ have been listed. Note that where the classifier has evidence for a different compound for one of these Group Entries, then they should use the Conversion Factor for that compound, which in turn, might affect the relative position of the Group Entry in Table 3.

\subsection{What is worst case?}

The approach to assessing worst case inorganic compounds is to calculate how much of the metal, for a given metal species, is required to create a hazardous outcome. For most species, this outcome is based on:

- the size of the Conversion Factor (note that a larger conversion factor does necessarily equate to a more hazardous species), and

- which hazard statements a given compound has and by correlation, the thresholds defined in the LoW.

Other factors that could influence the outcome include:

- Whether the compounds is a Note 1 substance e.g. lead chromate.

- Whether the compound has a threshold defined at technical guidance level e.g. HP 12: (EUH031, EUH032) and HP 3 (fifth indent).

- Whether the harmonized entry is an incomplete entry and missing one or more hazard classes (e.g. barium salts).

- Whether the harmonised entry is a minimum entry ${ }^{9}$. For example, mercury dichloride has "H300 Acute Tox. 2*", threshold 0.25\% butitcouldbeAcuteTox. 1,threshold $0.1 \%$.

The approach also has two important caveats that cannot be factored into a worst case assessment:

- With a few exceptions, the assessment doesn't assess the contribution of the physical hazards, HP 1, HP 2 and HP 3 and HP 12 (and related hazard statement's category code marked $* \star \star \star)$. This is because a) there are no published thresholds and $b$ ) it depends on synergistic/antagonistic effects with other components in the waste; some components may increase the physical hazard while others may mitigate the hazard. There are calculation methods for HP 3 flammable: fifth indent (Water-react. 1; H260 and also H261) and HP 12 (EUH031, EUH032), detailed in WM3 (2018) \& EU (2018), which have been included in this review.

- The assessment does not take into account additivity of the selected species with other additive substances present in the same waste. HP 4, HP 5, HP 6, HP 8 and HP 14 all have one or more additive hazard statements. Additivity can therefore make a waste hazardous at lower concentrations than that of the individual concentration of the substance alone.

It must also be noted that the CLP considers that all the harmonized entries in CLP Table 3 may be incomplete with respect to hazard classes that are not listed for given entry.

For substances that are known to be incomplete (for example all the refined petroleum hydrocarbon entries) and haven't been amended since the publication of ATP 2 (EU 2011), when Note $H^{10}$ was removed, or for the millions of substances that are not listed in CLP Table 3, the classifier is responsible for self-classification; this means checking other sources including ECHA's C\&L Inventory (C\&L 2020), REACH compliant SDS and other sources such as IARC (2020). With respect to the self-classifications for a given non-harmonized substance in the C\&L Inventory, the guid- 
ance recommends assessing those hazard statements having the higher number of notifiers.

One further example of an incomplete entry (that was also not marked as Note $\mathrm{H}$ ) is the Group Entry for barium salts mentioned above. Two Group Entries need to be reviewed:

- barium salts, with the exception of barium sulphate, salts of 1-azo-2-hydroxynaphthalenyl aryl sulphonic acid, and of salts specified elsewhere in this Annex, and

chromium (VI) compounds, with the exception of barium chromate and of compounds specified elsewhere in this Annex.

Both would imply that you would expect barium chromate to be a harmonized entry in CLP Table 3 as all chromates are carcinogenic (threshold $0.1 \%, \mathrm{HP} 7$ ). However, barium chromate is missing from CLP Table 3 and the unwary classifier could easily use the barium salts Group Entry (threshold 22.5\%, HP 6) and thus seriously misclassify their waste. Indeed, as barium salts is a Note 1 entry (i.e. you can use the total barium concentration only in the calculations; threshold $22.5 \%$ ), you could actually have a barium chromate concentration of $41.5 \%$ in the waste if the Conversion Factor (1.845) for barium to barium chromate were to be applied.

\section{RANKING PROTOCOL}

The paper focusses primarily on the harmonized entries for simple inorganics compounds published in CLP Table 3. However, this paper's Table 3 also contains a number of extra entries from HazWasteOnline ${ }^{\mathrm{TM}}$, which are not harmonised entries. Non-harmonised entries are required to:

- help assess mixtures such as contaminated soils where non-CLP substances like chromium(III) oxide need to be managed; [they are also needed for many organic compounds such as unknown oil and several of the standard PAHs e.g. anthracene, pyrene].

- accommodate non-CLP substances that are named or implied in Group Entries, such as barium chromate.

The ranking process is quite straight forward; it is primarily based on which hazard statements a compound has and, with a few exceptions (like Note 1), on its compound concentration.

For a given metal, only the simpler inorganic compounds, published in CLP Table 3 (plus a number of non-harmonized species) have been assessed. There are many CLP compounds (such as chemical industry intermediates) that are not included in this assessment. If the classifier suspects that such a compound or a non-harmonised compound could be present in their waste, then they should add that compound to their assessment and include lines of evidence to discount the more hazardous compounds where necessary.

The exercise encountered a number of issues that required a further methodology for deciding some species' ranking. These were:

- As discussed in section 6.3, out of the thirteen Group
Entries detailed in Table 3, six of them (arsenic salts, beryllium, chromium( $\mathrm{VI})$, selenium, thallium and uranium) are not marked Note 1 and need a suitable Conversion Factor. Conversion Factors for other (non-harmonised) species have been documented but the classifier should adjust accordingly if they have evidence for a different species.

Where a number of metal species (primarily for species of cadmium, cobalt and lead) are both Note 1 and have the same hazard statement (so the same threshold), the species are ordered using the following approach;

1. For a given class e.g. carcinogenic, the higher category code is listed first - e.g. Carc. 1A; H350, before Carc. 1B; H350, and then

2. For two or more species with the same category code e.g. Carc. 1B, the species with the higher Conversion Factor (CF) is listed first. For example, a species with a CF of 1.6 ranks higher than one with a CF of 1.5 .

Other factors that have a bearing:

- M factors ${ }^{5}$ defined in CLP Table 3 are currently not implemented in the waste legislation, so are not considered in this paper.

- The concentration limits in the Annex III amendment (EU 2014b) do not apply to metal alloys in their massive form (assuming they are not contaminated with hazardous substances). The only exception to this rule (at the time of writing) is amalgam waste from dental care, 1801 10*. An alloy is a mixture of two or more metallic elements, so for example, steel (17 0405$)$ is an alloy of iron and carbon and copper (as in pipe, 1704 01), while a minimum of $99.9 \%$ copper, can be alloyed with up to $0.04 \%$ phosphorous. The term "massive", while not defined in the waste legislation, is generally accepted to be particles $\geq 1 \mathrm{~mm}$; a size used to differentiate between nickel powders in ATP 1 (EU 2009) and lead powders in ATP 9 (EU 2016). However, ATP 15 (EU 2020) recently added granulated copper to CLP Table 3 for particle lengths of 0.9 to $6.0 \mathrm{~mm}$ and width 0.494 to $0.949 \mathrm{~mm}$.

- Whether a metal species is hazardous at a particular metal concentration is also dependent on whether a given metal concentration is reported as a dry weight or an as-received (wet weight) metal concentration. Laboratory analysis of metals (typically aqua regia extraction and ICP-OES ${ }^{11}$ ) is done on the dried material and reported in dry weight terms. Unlike the WAC assessment however, water is an integral component of the waste, so any dry weight concentrations should be converted back to their as-received equivalent before a waste classification is undertaken.

- The analysis has not considered hydrated forms where the hydrous form is not listed in CLP Table 3.

\subsection{Anhydrous and hydrous forms}

Out of the 204 entries in Table 3, only copper and zinc have defined entries for both the anhydrous and one or more hydrated forms. The CLP makes it clear that where the hydrated form is not present in CLP Table 3 , the classifier can use the hazard statements from the anhydrous 
form. However, in this case, the classifier also has to apply a suitable Conversion Factor to account for one or more water molecules; a Conversion Factor that will be larger than that for the anhydrous molecule (i.e. the hydrated molecule will be hazardous at lower cation concentrations than the anhydrous molecule). If the classifier is considering a metal species that has hydrous forms (and also not listed in Table 3), then they will have to consider applying a suitable Conversion Factor.

\subsection{Most characteristic metal}

One other lesser known but useful fact can be discerned from the first three digits of the CLP index number in CLP Table 3. The CLP states that "Entries in Part 3 [i.e. Table 3] are listed according to the atomic number of the element most characteristic of the properties of the substance". So the first three digits of the index number indicate either the atomic number of the key element or if in the 600 s, the organic group that is most characteristic with respect to the hazard properties. For example:

- 082-011-00-0 lead hydrogen arsenate, $\mathrm{PbHAsO}_{4}$ : 082 refers to lead and not arsenic

- 024-007-00-3 zinc chromate, $\mathrm{ZnCrO}_{4}$ : 024 refers to chromium and not zinc

- 615-017-00-4 calcium cyanamide, $\mathrm{CaCN}_{2}$ : 615 refers to cyanamide anion

This information has been included in Table 2 and later in Table 3, where the most characteristic element or organic group, where defined by a CLP index number, is emboldened in the chemical formula.

\subsection{Metal species containing two metals}

A potential conflict arrives in the listings when a species contains more than one hazardous metal, for example, lead hydrogen arsenate, selenium compounds like nickel selenite and all the chromates. Considering the chromates, should a chromate be listed under the cation (e.g. zinc for zinc chromate) or under chromium, as a given species can be hazardous by either metal but at different concentrations. Practically, this is also an important consideration for classifiers when assessing whether a particular species can be present or not.

To explore this conflict further, it is also helpful to be able to refer to the metal with the highest concentration that triggers a hazardous outcome, defined here as the primary metal (effectively the element with the largest relative atomic mass), the other(s) being referred to as the secondary metal(s). For example, $361 \mathrm{mg} / \mathrm{kg}$ of zinc, in the form of zinc chromate, would trigger HP 7 at $1,000 \mathrm{mg} / \mathrm{kg}$. Within this total, $361 \mathrm{mg} / \mathrm{kg}$ is zinc while only $287 \mathrm{mg} / \mathrm{kg}$ is chromium $(\mathrm{VI})^{12}$. Here, zinc is the primary metal, and chromium the secondary metal.

Calculating the concentration of the secondary metal (sometimes referred to as the limiting concentration) is useful because if the laboratory reports significantly ${ }^{13}$ lower concentrations of the secondary metal, the classifier can make the case that there isn't enough chromium(VI) to make hazardous concentrations of zinc chromate and then move on to the next less worst case species.

To highlight the issues around ordering by either the cation or in the case of chromates, by chromium(VI) and to examine the distribution of the primary and secondary metals, Table 2 shows a selection of metal chromates ordered from worst case cation to less worst case; Table 2a in terms of the cation and Table $2 b$ in terms of chromium. With one exception (lead chromate, Note 1), the tables list the relative concentrations of both the metal cation and of chromium $(\mathrm{VI})$ relative to the hazardous threshold of 1,000 $\mathrm{mg} / \mathrm{kg}$ for HP 7. Clearly, one table is simply the reverse of the other (Note 1 excepted) as we are dealing with the same atomic ratios.

Both the orders shown in Table 2 have their uses depending on whether you are considering the cation concentration or the concentration of chromium(VI). It is also clear that chromium is the primary metal for calcium and sodium chromate, and the dichromates, but for all the other chromates, the cation is the primary metal. So, for metals species containing two metals, knowledge about which is the primary metal doesn't help us pick one ordering system over another.

Finally determining which is the primary metal is more important where the compound is marked Note 1 , such as in the case of lead chromate above or lead hydrogen arsenate, where the lead is primary and arsenic is secondary. The determination is more critical because in these cases, more of both the primary and secondary metals can be present before a hazardous threshold is reached.

\subsection{Ranking protocol decision}

The result of reviewing both the primary/secondary metals and the most characteristic metal confirms that there is no simple method for worst case listing by either the primary metal or the characteristic metal. In reality, workers test a) for a subset of metals, which rarely include tests for many potentially primary elements such as $\mathrm{Ca}$, $\mathrm{Na}, \mathrm{K}, \mathrm{S}, \mathrm{P}, \mathrm{O}, \mathrm{N}, \mathrm{Cl}$ etc. and b) most workers see their heavy metals as the key reference point, so for example, will intuitively look at a list of zinc compounds when considering zinc and not necessarily consider the chromium in zinc chromate on the first pass.

So in this paper we have compromised and listed primarily by the cation but with a few examples of some compounds listed twice (e.g. lead hydrogen arsenate (where arsenic is secondary) or nickel selenite (where selenium is primary) to try and remind the classifier that they should consider both the primary metal and the secondary metal in their work.

Table 3 contains 32 elements and 204 metal species, listed from worst case to less worst case for each metal. For each entry, the table documents (by column number):

1. Which hazard property triggers first.

2. Whether the substance has one or more additive hazard statements $(\Sigma)$.

3. Which hazard property hasn't been or can't be evaluated e.g. HP 3.

4. Which hazard statement caused the trigger.

5. The threshold concentration for that hazard statement, in $\%$. (For reference $0.1 \%=1,000 \mathrm{mg} / \mathrm{kg}$ ).

6. Except for the rows highlighted in green, the name of the entry as published in CLP Table 3.

7. The molecular formula, with the characteristic element 
TABLE 2: List of worst case to less worst case for the CLP Table 3 chromates ordered from worst case to less worst case. In Table 2a the order is defined by the concentration of the cation. In Table $2 b$ the order is defined by the concentration of chromium. The primary metal for each compound is shown in red while the secondary remains in black. (Barium chromate is not a harmonised entry and is self-classified (refer Table 3).) Embolden text in the chemical formula shows most characteristic element as defined by the entry's index number in CLP Table 3

\begin{tabular}{|c|c|c|c|}
\hline & $\begin{array}{l}\text { 呈 } \\
\text { 芯 } \\
\text { 立 }\end{array}$ & $\begin{array}{c}\text { Triggering hazard } \\
\text { statement }\end{array}$ & $\begin{array}{l}\text { 웅 } \\
\text { 응 } \\
\text { 동 } \\
\text { 는 }\end{array}$ \\
\hline \multicolumn{4}{|l|}{ chromates } \\
\hline & HP7 & Carc 1A/1B; H350 & 0.1 \\
\hline
\end{tabular}

Table 2a Ordered in terms of the cation

\begin{tabular}{|c|c|c|c|c|c|c|}
\hline \multirow{2}{*}{ Species } & \multirow{2}{*}{$\begin{array}{l}\text { Compound Conc. } \\
\mathrm{mg} / \mathrm{kg}\end{array}$} & \multirow[b]{2}{*}{ Formula } & $\downarrow \mathbf{m g} / \mathbf{k g}$ & CF & $\mathbf{m g} / \mathbf{k g}$ & CF \\
\hline & & & \multicolumn{2}{|c|}{ cation } & \multicolumn{2}{|c|}{ chromium(VI) } \\
\hline ammonium dichromate & 1,000 & $\left(\mathrm{NH}_{4}\right)_{2} \mathrm{Cr}_{2} \mathrm{O}_{7}$ & 143 & 6.987 & 413 & 2.424 \\
\hline sodium dichromate & 1,000 & $\mathrm{Na}_{2} \mathrm{Cr}_{2} \mathrm{O}_{7}$ & 176 & 5.697 & 397 & 2.519 \\
\hline nickel dichromate & 1,000 & $\mathrm{NiCr}_{2} \mathrm{O}_{7}$ & 214 & 4.680 & 379 & 2.641 \\
\hline calcium chromate & 1,000 & $\mathrm{CaCrO}_{4}$ & 257 & 3.894 & 333 & 3.002 \\
\hline potassium dichromate & 1,000 & $\mathrm{~K}_{2} \mathrm{Cr}_{2} \mathrm{O}_{7}$ & 266 & 3.762 & 353 & 2.829 \\
\hline sodium chromate & 1,000 & $\mathrm{Na}_{2} \mathrm{CrO}_{4}$ & 284 & 3.523 & 321 & 3.115 \\
\hline nickel chromate & 1,000 & $\mathrm{NiCrO}_{4}$ & 336 & 2.976 & 298 & 3.360 \\
\hline zinc chromate & 1,000 & $\mathrm{ZnCrO}_{4}$ & 361 & 2.774 & 287 & 3.488 \\
\hline potassium chromate & 1,000 & $\mathrm{~K}_{2} \mathrm{CrO}_{4}$ & 403 & 2.483 & 268 & 3.735 \\
\hline strontium chromate & 1,000 & $\mathrm{SrCrO}_{4}$ & 430 & 2.324 & 255 & 3.916 \\
\hline barium chromate & 1,000 & $\mathrm{BaCrO}_{4}$ & 543 & 1.845 & 205 & 4.872 \\
\hline lead chromate & 1,000 & $\mathrm{PbCrO}_{4}$ & 641 & 1.560 & 161 & 6.216 \\
\hline lead chromate (Note 1 ) & 1,560 & $\mathrm{~Pb}$ & 1,000 & 1.000 & 251 & 6.216 \\
\hline \multicolumn{7}{|c|}{ Table $\mathbf{2 b}$ Ordered in terms of chromium } \\
\hline \multirow{2}{*}{ Species } & \multirow{2}{*}{$\begin{array}{l}\text { Compound Conc. } \\
\mathrm{mg} / \mathrm{kg}\end{array}$} & & $\mathbf{m g} / \mathbf{k g}$ & CF & $\downarrow \mathbf{m g} / \mathbf{k g}$ & $\mathrm{CF}$ \\
\hline & & Formula & \multicolumn{2}{|c|}{ cation } & \multicolumn{2}{|c|}{ chromium(VI) } \\
\hline lead chromate & 1,000 & $\mathrm{PbCrO}_{4}$ & 641 & 1.560 & 161 & 6.216 \\
\hline barium chromate & 1,000 & $\mathrm{BaCrO}_{4}$ & 543 & 1.845 & 205 & 4.872 \\
\hline lead chromate (Note 1) & 1,560 & $\mathrm{~Pb}$ & 1,000 & 1.000 & 251 & 6.216 \\
\hline strontium chromate & 1,000 & $\mathrm{SrCrO}_{4}$ & 430 & 2.324 & 255 & 3.916 \\
\hline potassium chromate & 1,000 & $\mathrm{~K}_{2} \mathrm{CrO}_{4}$ & 403 & 2.483 & 268 & 3.735 \\
\hline zinc chromate & 1,000 & $\mathrm{ZnCrO}_{4}$ & 361 & 2.774 & 287 & 3.488 \\
\hline nickel chromate & 1,000 & $\mathrm{NiCrO}_{4}$ & 336 & 2.976 & 298 & 3.360 \\
\hline sodium chromate & 1,000 & $\mathrm{Na}_{2} \mathrm{CrO}_{4}$ & 284 & 3.523 & 321 & 3.115 \\
\hline calcium chromate & 1,000 & $\mathrm{CaCrO}_{4}$ & 257 & 3.894 & 333 & 3.002 \\
\hline potassium dichromate & 1,000 & $\mathrm{~K}_{2} \mathrm{Cr}_{2} \mathrm{O}_{7}$ & 266 & 3.762 & 353 & 2.829 \\
\hline nickel dichromate & 1,000 & $\mathrm{NiCr}_{2} \mathrm{O}_{7}$ & 214 & 4.680 & 379 & 2.641 \\
\hline sodium dichromate & 1,000 & $\mathrm{Na}_{2} \mathrm{Cr}_{2} \mathrm{O}_{7}$ & 176 & 5.697 & 397 & 2.519 \\
\hline ammonium dichromate & 1,000 & $\left(\mathrm{NH}_{4}\right)_{2} \mathrm{Cr}_{2} \mathrm{O}_{7}$ & 143 & 6.987 & 413 & 2.424 \\
\hline
\end{tabular}

shown in bold and where applicable, Note 1 shown to indicate that the metal concentration should be used in the calculations.

8. The substance's CAS registry number.

9. The concentration of the metal in $\mathrm{mg} / \mathrm{kg}$, required to trigger the hazardous outcome.

10. The conversion factor ${ }^{14}$.

It is also interesting to note that of the 204 species in Table 3 , the vast majority (94\%) are additive, having one or more additive hazard statements. The remaining $6 \%$ are dominated by entries with only a single (non-additive) hazard statement.

\section{EXAMPLE: WORKING FROM WORST CASE TO LESS WORST CASE}

So the next critical question is how does the classifier work from worst case to a more reasonable case. The guidance advises the use of lines of evidence to achieve this. 
TABLE 3: List of worst case to less worst case metal species, grouped by element, listed worst case to less worst case.

\begin{tabular}{|c|c|c|c|c|c|c|c|c|c|c|}
\hline 焉 & 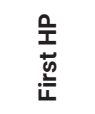 & 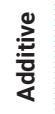 & 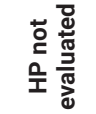 & $\begin{array}{l}\text { Triggering hazard } \\
\text { statement }\end{array}$ & $\frac{1}{\bar{d}} \frac{\circ}{\mathrm{L}}$ & $\begin{array}{l}\text { Metal species } \\
\text { / CLP entry }\end{array}$ & $\begin{array}{l}\text { Molecular } \\
\text { formula }\end{array}$ & $\begin{array}{l}\text { CAS No. } \\
\text { of CLP } \\
\text { entry }\end{array}$ & $\begin{array}{c}\text { Conc. lim- } \\
\text { it of metal } \\
\mathrm{mg} / \mathrm{kg}\end{array}$ & $\begin{array}{c}\text { Conver. } \\
\text { Factor } \\
\text { (CF) }\end{array}$ \\
\hline \multirow[t]{3}{*}{ Al 013} & HP 6 & $\Sigma$ & & Acute Tox.1; H330 A, B & 0.1 & aluminium phosphide & AIP & 20859-73-8 & 466 & 2.148 \\
\hline & HP 3 & & HP3(ii) & Water-react. 2; H261 A & 0.1 & aluminium powder & Al & 7429-90-5 & 1000 & 1.000 \\
\hline & HP 8 & $\Sigma$ & & Skin Corr. 1B; H314 & 5.0 & aluminium chloride & $\mathrm{AlCl}_{3}$ & $7446-70-0$ & 10,118 & 4.942 \\
\hline \multirow[t]{5}{*}{ Sb 051} & HP 7 & & & Carc. 2; H351 & 1.0 & antimony trioxide & $\mathrm{Sb}_{2} \mathrm{O}_{3}$ & 1309-64-4 & 8,354 & 1.197 \\
\hline & HP 14 & $\Sigma$ & & Aquatic Chronic 2; H411 & 2.5 & antimony pentachloride & $\mathrm{SbCl}_{5}$ & 7647-18-9 & 10,180 & 2.456 \\
\hline & HP 14 & $\Sigma$ & & Aquatic Chronic 2; H411 & 2.5 & antimony trichloride & $\mathrm{SbCl}_{3}$ & $10025-91-9$ & 13,344 & 1.874 \\
\hline & HP 14 & $\Sigma$ & & Aquatic Chronic 2; H411 & 2.5 & antimony trifluoride & $\mathrm{SbF}_{3}$ & $7783-56-4$ & 17,029 & 1.468 \\
\hline & HP 14 & $\Sigma$ & & Aquatic Chronic 2; H411 & 2.5 & $\begin{array}{l}\text { antimony compounds with } \\
\text { the exception of tetroxide ... }\end{array}$ & $\begin{array}{c}\text { Sb } \\
\text { (Note 1) }\end{array}$ & - & 25,000 & 1.000 \\
\hline \multirow[t]{6}{*}{ As 033} & HP 7 & $\Sigma$ & & Carc. 1A; H350 & 0.1 & lead hydrogen arsenate & $\begin{array}{l}\mathrm{PbHAsO}_{4} \\
(\text { Note } 1)^{2}\end{array}$ & $7784-40-9$ & \multicolumn{2}{|c|}{ see lead } \\
\hline & HP 7 & $\Sigma$ & & Carc. 1A; H350 & 0.1 & $\begin{array}{c}\text { arsenic acid and its salts } \\
\text { with the exception of } \\
\text { those ... }\end{array}$ & as $\mathrm{H}_{3} \mathrm{AsO}_{4}$ & - & 528 & 1.895 \\
\hline & HP 7 & $\Sigma$ & & Carc. 1A; H350 & 0.1 & arsenic pentoxide & $\mathrm{As}_{2} \mathrm{O}_{5}$ & $1303-28-2$ & 652 & 1.534 \\
\hline & HP 7 & $\Sigma$ & & Carc. 1A; H350 & 0.1 & arsenic trioxide & $\mathrm{As}_{2} \mathrm{O}_{3}$ & $1327-53-3$ & 758 & 1.320 \\
\hline & HP 7 & $\Sigma$ & & Carc. $1 \mathrm{~A} ; \mathrm{H} 350^{\mathrm{C}}$ & 0.1 & arsenic & As & $7440-38-2$ & 1000 & 1.000 \\
\hline & HP 7 & $\Sigma$ & & Carc. $1 \mathrm{~A} ; \mathrm{H} 350^{\mathrm{C}}$ & 0.1 & $\begin{array}{l}\text { arsenic compounds, with } \\
\text { the exception of those ... }\end{array}$ & $\begin{array}{c}\text { As } \\
\text { (Note 1) }\end{array}$ & - & 1000 & 1.000 \\
\hline \multirow[t]{8}{*}{$\mathrm{Ba} 056$} & HP 7 & $\Sigma$ & HP 2 & Carc. 1B; H350 & 0.1 & barium chromate ${ }^{F}$ & $\mathrm{BaCrO}_{4}$ & $10294-40-3$ & 543 & 1.845 \\
\hline & HP 12 & $\Sigma$ & & EUH031 в & 0.8 & barium sulphide & BaS & $21109-95-5$ & 6,486 & 1.233 \\
\hline & HP 14 & $\Sigma$ & HP 2 & Aquatic Chronic 2; H411 & 2.5 & barium chlorate & $\mathrm{Ba}\left(\mathrm{CIO}_{3}\right)_{2}$ & $13477-00-4$ & 11,285 & 2.215 \\
\hline & HP 6 & $\Sigma$ & & Acute Tox. 3; H301 & 5.0 & barium chloride & $\mathrm{BaCl}_{2}$ & $10361-37-2$ & 32,975 & 1.516 \\
\hline & $\begin{array}{l}\text { HP } 6 \\
\text { HP } 8\end{array}$ & $\Sigma$ & & $\begin{array}{l}\text { Acute Tox. 3; H301 } \\
\text { Skin Corr. 1B; H314 }\end{array}$ & 5.0 & barium oxide ${ }^{G}$ & $\mathrm{BaO}$ & $1304-28-5$ & 44,783 & 1.117 \\
\hline & HP 6 & $\Sigma$ & & Acute Tox 4; H302 & 25.0 & barium carbonate & $\mathrm{BaCO}_{3}$ & 513-77-9 & 173,977 & 1.437 \\
\hline & HP 6 & $\Sigma$ & & Acute Tox 4; H332 & 22.5 & $\begin{array}{l}\text { barium salts, with the } \\
\text { exception of barium sul- } \\
\text { phate, and those ... }\end{array}$ & $\begin{array}{c}\text { Ba } \\
(\text { Note 1) }\end{array}$ & - & 225,000 & 1.000 \\
\hline & - & - & & - & - & barium sulfate ${ }^{\mathrm{H}}$ & $\mathrm{BaSO}_{4}$ & $7727-43-7$ & - & 1.700 \\
\hline \multirow[t]{5}{*}{ Be 004} & HP 7 & $\Sigma$ & & Carc. 1B; $\mathrm{H} 350^{\mathrm{D}}$ & 0.1 & $\begin{array}{l}\text { aluminium beryllium } \\
\text { silicates }\end{array}$ & $\begin{array}{c}\text { as } \\
\mathrm{Al}_{2} \mathrm{Be}_{3} \mathrm{Si}_{6} \mathrm{O}_{18} \\
\text { as } \\
\mathrm{Al}_{2} \mathrm{Be}_{2} \mathrm{Si}_{5} \mathrm{O}_{15}\end{array}$ & $\begin{array}{l}1302-52-9 \\
37220-37-4\end{array}$ & 40 & $\begin{array}{l}19.880 \\
25.099\end{array}$ \\
\hline & HP 7 & $\Sigma$ & & Carc. 1B; H350 & 0.1 & beryllium chloride ' & $\mathrm{BeCl}_{2}$ & $7787-47-5$ & 113 & 8.868 \\
\hline & HP 7 & $\Sigma$ & & Carc. 1B; H350 & 0.1 & $\begin{array}{l}\text { beryllium compounds with } \\
\text { the exception of aluminium } \\
\text { beryllium silicates, and } \\
\text { those ... }\end{array}$ & $\begin{array}{l}\text { Be as } \mathrm{BeCl}_{2} \\
\text { as } \mathrm{Be}(\mathrm{OH})_{2}\end{array}$ & - & $\begin{array}{l}113 \\
210\end{array}$ & $\begin{array}{l}8.868 \\
4.774\end{array}$ \\
\hline & HP 7 & $\Sigma$ & & Carc. 1B; H350 & 0.1 & beryllium oxide & $\mathrm{BeO}$ & 1304-56-9 & 361 & 2.775 \\
\hline & HP 7 & $\Sigma$ & & Carc. 1B; H350 & 0.1 & beryllium & $\mathrm{Be}$ & $7440-41-7$ & 1,000 & 1.000 \\
\hline \multirow[t]{5}{*}{ В 005} & HP 6 & $\Sigma$ & & Acute Tox. 2; $\mathrm{H} 300$ & 0.25 & boron tribromide & $\mathrm{BBr}_{3}$ & $10294-33-4$ & 108 & 23.173 \\
\hline & HP 6 & $\Sigma$ & & Acute Tox. 2; H30O & 0.25 & boron trichloride & $\mathrm{BCl}_{3}$ & $10294-34-5$ & 231 & 10.838 \\
\hline & HP 10 & & & Repr. 1B; H360 & 0.3 & boric acid & $\mathrm{H}_{3} \mathrm{BO}_{3}$ & $\begin{array}{l}10043-35-3 \\
11113-50-1\end{array}$ & 525 & 5.719 \\
\hline & HP 6 & $\Sigma$ & & Acute Tox. 2; H330 & 0.5 & boron trifluoride & $\mathrm{BF}_{3}$ & 7637-07-2 & 798 & 6.272 \\
\hline & HP 10 & & & Repr. 1B; H360 & 0.3 & diboron trioxide; boric oxide & $\mathrm{B}_{2} \mathrm{O}_{3}$ & $1303-86-2$ & 932 & 3.220 \\
\hline \multirow[t]{2}{*}{ Cd 048} & $\begin{array}{l}\text { HP } 7 \\
\text { HP } 11\end{array}$ & $\Sigma$ & & $\begin{array}{l}\text { Carc. 1B; H350 } \\
\text { Muta. 1B; H340 }\end{array}$ & 0.1 & cadmium sulphate & $\mathrm{CdSO}_{4}$ & $10124-36-4$ & 540 & 1.855 \\
\hline & $\begin{array}{l}\text { HP } 7 \\
\text { HP } 11\end{array}$ & $\Sigma$ & & $\begin{array}{l}\text { Carc. 1B; H350 } \\
\text { Muta. 1B; H340 }\end{array}$ & 0.1 & cadmium chloride & $\mathrm{CdCl}_{2}$ & $10108-64-2$ & 614 & 1.631 \\
\hline
\end{tabular}




\begin{tabular}{|c|c|c|c|c|c|c|c|c|c|c|}
\hline ल & 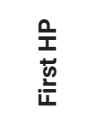 & 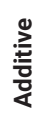 & 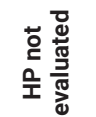 & $\begin{array}{l}\text { Triggering hazard } \\
\text { statement }\end{array}$ & $\frac{1}{\bar{y}} \frac{\circ}{2}$ & $\begin{array}{l}\text { Metal species } \\
\text { / CLP entry }\end{array}$ & $\begin{array}{l}\text { Molecular } \\
\text { formula }\end{array}$ & $\begin{array}{l}\text { CAS No. } \\
\text { of CLP } \\
\text { entry }\end{array}$ & $\begin{array}{l}\text { Conc. lim- } \\
\text { it of metal } \\
\mathrm{mg} / \mathrm{kg}\end{array}$ & $\begin{array}{l}\text { Conver. } \\
\text { Factor } \\
\text { (CF) }\end{array}$ \\
\hline & $\begin{array}{l}\text { HP } 7 \\
\text { HP } 11\end{array}$ & $\Sigma$ & & $\begin{array}{l}\text { Carc. 1B; H350 } \\
\text { Muta. 1B; H340 }\end{array}$ & 0.1 & cadmium fluoride & $\mathrm{CdF}_{2}$ & $7790-79-6$ & 748 & 1.338 \\
\hline & HP 14 & $\Sigma$ & & Aquatic Chronic $1 ; \mathrm{H} 410$ & 0.25 & cadmium iodide & $\mathrm{CdI}_{2}$ & $7790-80-9$ & 768 & 3.258 \\
\hline & HP 7 & $\Sigma$ & & Carc. 1B; H350 & 0.1 & cadmium oxide & $\mathrm{CdO}$ & $1306-19-0$ & 876 & 1.142 \\
\hline & $\begin{array}{l}\text { HP } 7 \\
\text { HP } 11\end{array}$ & $\Sigma$ & & $\begin{array}{l}\text { Carc. 1B; H350 } \\
\text { Muta. 1B; H340 }\end{array}$ & 0.1 & cadmium nitrate & $\begin{array}{l}\mathrm{Cd}\left(\mathrm{NO}_{3}\right)_{2} \\
(\text { Note 1) }\end{array}$ & $10325-94-7$ & 1,000 & 2.103 \\
\hline & $\begin{array}{l}\text { HP } 7 \\
\text { HP } 11\end{array}$ & $\Sigma$ & & $\begin{array}{l}\text { Carc. 1B; H350 } \\
\text { Muta. 1B; H340 }\end{array}$ & 0.1 & cadmium carbonate & $\begin{array}{l}\mathrm{CdCO}_{3} \\
\text { (Note 1) }\end{array}$ & $513-78-0$ & 1,000 & 1.534 \\
\hline & $\begin{array}{l}\text { HP } 7 \\
\text { HP } 11\end{array}$ & $\Sigma$ & & $\begin{array}{l}\text { Carc. 1B; H350 } \\
\text { Muta. 1B; H340 }\end{array}$ & 0.1 & cadmium hydroxide & $\begin{array}{l}\mathrm{Cd}(\mathrm{OH})_{2} \\
(\text { Note 1) }\end{array}$ & $21041-95-2$ & 1,000 & 1.303 \\
\hline & HP 7 & $\Sigma$ & & Carc. 1B; H350 & 0.1 & cadmium sulfide & $\begin{array}{l}\text { CdS } \\
\text { (Note 1) }\end{array}$ & $1306-23-6$ & 1,000 & 1.285 \\
\hline & HP 7 & $\Sigma$ & $\mathrm{HP} 3$ & Carc. 1B; H350 & 0.1 & cadmium & Cd & $7440-43-9$ & 1,000 & 1.000 \\
\hline & HP 7 & $\Sigma$ & & Carc. 1B; H350 D & 0.1 & $\begin{array}{l}\text { cadmium compounds with } \\
\text { the exception of cadmium } \\
\text { sulphoselenide... and ... }\end{array}$ & $\begin{array}{c}\text { Cd } \\
\text { (Note 1) }\end{array}$ & - & 1,000 & 1.000 \\
\hline & HP 14 & $\Sigma$ & & Aquatic Chronic $1 ; \mathrm{H} 410$ & 0.25 & cadmium hexafluorosilicate & $\mathrm{CdF}_{6} \mathrm{Si}$ & $17010-21-8$ & 1,105 & 2.264 \\
\hline & HP 14 & $\Sigma$ & & Aquatic Chronic $1 ; \mathrm{H} 410$ & 0.25 & cadmium diformate & $\mathrm{CdC}_{2} \mathrm{H}_{2} \mathrm{O}_{4}$ & $4464-23-7$ & 1,389 & 1.801 \\
\hline & $\begin{array}{l}\text { HP } 6 \\
\text { HP } 14\end{array}$ & $\Sigma$ & & $\begin{array}{c}\text { Acute Tox. 2; H300 } \\
\text { Acute Tox. } 1 ; \mathrm{H} 310 \\
\text { Aquatic Chronic } 1 ; \mathrm{H} 410\end{array}$ & 0.25 & cadmium cyanide & $\mathrm{Cd}(\mathrm{CN})_{2}$ & $542-83-6$ & 1,709 & 1.463 \\
\hline & $\begin{array}{l}\text { HP } 4 \\
\text { HP } 5\end{array}$ & $\Sigma$ & & $\begin{array}{l}\text { Skin Irrit. 2; H315 } \\
\text { STOT SE 3; H335 }\end{array}$ & 20.0 & $\underset{\operatorname{red}^{\mathrm{E}}}{\operatorname{cadmium} \text { slfolenide }}$ & $\mathrm{Cd}_{2} \mathrm{SSe}$ & $58339-34-7$ & 133,869 & 1.494 \\
\hline \multirow[t]{12}{*}{ Ca 020} & HP 7 & $\Sigma$ & & Carc. 1B; H350 & 0.1 & calcium chromate & $\mathrm{CaCrO}_{4}$ & $13765-19-0$ & 257 & 3.894 \\
\hline & HP 6 & $\Sigma$ & HP 12 & Acute Tox. 1; H330 & 0.1 & calcium phosphide & $\mathrm{Ca}_{3} \mathrm{P}_{2}$ & $1305-99-3$ & 660 & 1.515 \\
\hline & HP 12 & $\Sigma$ & & EUH032 ${ }^{\text {в }}$ & 0.2 & calcium cyanide & $\mathrm{Ca}(\mathrm{CN})_{2}$ & $592-01-8$ & 871 & 2.298 \\
\hline & HP 3 & & & Water-react. 1; H260 A & 0.1 & calcium hydride & $\mathrm{CaH}_{2}$ & 7789-78-8 & 953 & 1.050 \\
\hline & HP 12 & $\Sigma$ & & EUH031 в & 0.3 & calcium sulphide & $\mathrm{CaS}$ & $20548-54-3$ & 1,667 & 1.800 \\
\hline & HP 12 & $\Sigma$ & HP 2 & EUH031 в & 0.6 & calcium hypochlorite & $\mathrm{Ca}(\mathrm{OCl})_{2}$ & $7778-54-3$ & 1,682 & 3.568 \\
\hline & HP 3 & & & Water-react. $1 ; \mathrm{H} 260^{\mathrm{A}}$ & 0.3 & calcium carbide & $\mathrm{CaC}_{2}$ & $75-20-7$ & 1,876 & 1.599 \\
\hline & HP 3 & & & Water-react. 2; H261 A & 0.2 & calcium & $\mathrm{Ca}$ & $7440-70-2$ & 2,000 & 1.000 \\
\hline & HP 4 & $\Sigma$ & & Eye Dam. 1; H318 & 10.0 & calcium cyanamide & $\mathrm{CaCN}_{2}$ & $156-62-7$ & 50,034 & 1.999 \\
\hline & HP 4 & $\Sigma$ & & Eye Dam. 1; H318 & 10.0 & calcium hydroxide $^{\mathrm{J}}$ & $\mathrm{Ca}(\mathrm{OH})_{2}$ & $1305-62-0$ & 54,094 & 1.849 \\
\hline & HP 4 & $\Sigma$ & & Eye Dam. 1; H318 & 10.0 & calcium oxide ${ }^{\mathrm{K}}$ & $\mathrm{CaO}$ & $1305-78-8$ & 71,470 & 1.399 \\
\hline & HP4 & $\Sigma$ & & Eye Irrit. 2; H319 & 20.0 & calcium chloride & $\mathrm{CaCl}_{2}$ & $10043-52-4$ & 72,224 & 2.769 \\
\hline \multirow[t]{4}{*}{ Cr 024} & $\begin{array}{l}\text { HP } 7 \\
\text { HP } 11\end{array}$ & $\Sigma$ & HP 2 & $\begin{array}{l}\text { Carc. 1B; H350 } \\
\text { Muta. 1B; H340 }\end{array}$ & 0.1 & ammonium dichromate & $\left(\mathrm{NH}_{4}\right)_{2} \mathrm{Cr}_{2} \mathrm{O}_{7}$ & 7789-09-5 & 143 & 6.987 \\
\hline & HP 7 & $\Sigma$ & & Carc. 1B; H350 & 0.1 & $\begin{array}{l}\text { chromium }(\mathrm{VI}) \text { compounds, } \\
\text { with the exception of } \\
\text { barium chromate and ... }\end{array}$ & $\mathrm{Cr}$ as $\mathrm{H}_{2} \mathrm{CrO}_{4}$ & - & 441 & 2.270 \\
\hline & $\begin{array}{l}\text { HP } 7 \\
\text { HP } 11\end{array}$ & $\Sigma$ & HP 2 & $\begin{array}{l}\text { Carc. 1A; H350 } \\
\text { Muta. 1B; H340 }\end{array}$ & 0.1 & chromium $(\mathrm{VI})$ oxide & $\mathrm{CrO}_{3}$ & $1333-82-0$ & 520 & 1.923 \\
\hline & HP 13 & $\Sigma$ & & Skin Sens. 1; H317 & 10.0 & chromium(III) oxide ${ }^{\mathrm{E}}$ & $\mathrm{Cr}_{2} \mathrm{O}_{3}$ & $1308-38-9$ & 68,421 & 1.462 \\
\hline \multirow[t]{4}{*}{ Co 027} & HP 7 & $\Sigma$ & & Carc. 1B; H350 & 0.1 & cobalt dinitrate & $\begin{array}{l}\mathrm{Co}\left(\mathrm{NO}_{2}\right)_{2} \\
(\text { Note 1) }\end{array}$ & $10141-05-6$ & 1,000 & 3.104 \\
\hline & HP 7 & $\Sigma$ & & Carc. 1B; H350 & 0.1 & cobalt di(acetate) & $\begin{array}{l}\mathrm{Co}\left(\mathrm{C}_{2} \mathrm{H}_{3} \mathrm{O}_{2}\right)_{2} \\
(\text { Note 1) }\end{array}$ & $71-48-7$ & 1,000 & 3.004 \\
\hline & HP 7 & $\Sigma$ & & Carc. 1B; H350 & 0.1 & cobalt sulfate & $\begin{array}{l}\mathrm{CoSO}_{4} \\
\text { (Note 1) }\end{array}$ & $10124-43-3$ & 1,000 & 2.630 \\
\hline & HP 7 & $\Sigma$ & & Carc. 1B; H350 & 0.1 & cobalt dichloride & $\begin{array}{l}\mathrm{CoCl}_{2} \\
\text { (Note 1) }\end{array}$ & $7646-79-9$ & 1,000 & 2.203 \\
\hline
\end{tabular}




\begin{tabular}{|c|c|c|c|c|c|c|c|c|c|c|}
\hline$\sum_{\Sigma}^{\bar{d}}$ & 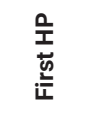 & 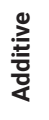 & 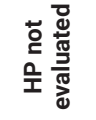 & $\begin{array}{l}\text { Triggering hazard } \\
\text { statement }\end{array}$ & $\begin{array}{l}\frac{1}{5} \text { 운 } \\
\text { 는 응 }\end{array}$ & $\begin{array}{l}\text { Metal species } \\
\text { / CLP entry }\end{array}$ & $\begin{array}{l}\text { Molecular } \\
\text { formula }\end{array}$ & $\begin{array}{l}\text { CAS No. } \\
\text { of CLP } \\
\text { entry }\end{array}$ & $\begin{array}{l}\text { Conc. lim- } \\
\text { it of metal } \\
\mathrm{mg} / \mathrm{kg}\end{array}$ & $\begin{array}{l}\text { Conver. } \\
\text { Factor } \\
\text { (CF) }\end{array}$ \\
\hline & HP 7 & $\Sigma$ & & Carc. 1B; H350 & 0.1 & cobalt carbonate & $\begin{array}{l}\mathrm{CoCO}_{3} \\
(\text { Note 1) }\end{array}$ & $513-79-1$ & 1,000 & 2.018 \\
\hline & HP 7 & $\Sigma$ & & Carc. 1B; H350 & 0.1 & cobalt & Co & $7440-48-4$ & 1,000 & 1.000 \\
\hline & HP 14 & $\Sigma$ & & Aquatic Chronic 1; H410 & 0.25 & cobalt sulfide & CoS & $1317-42-6$ & 1,620 & 1.544 \\
\hline & HP 14 & $\Sigma$ & & Aquatic Chronic $1 ; \mathrm{H} 410$ & 0.25 & cobalt oxide & $\mathrm{CoO}$ & $1307-96-6$ & 1,967 & 1.271 \\
\hline \multirow[t]{13}{*}{ Cu 029} & HP 14 & $\Sigma$ & & Aquatic Chronic 1; H410 & 0.25 & $\begin{array}{l}\text { copper sulphate } \\
\text { pentahydrate }\end{array}$ & $\mathrm{CuSO}_{4} \cdot 5 \mathrm{H}_{2} \mathrm{O}$ & 7758-99-8 & 637 & 3.929 \\
\hline & HP 14 & $\Sigma$ & & Aquatic Chronic 1; H410 & 0.25 & $\begin{array}{l}\text { copper(II) chloride } \\
\text { dihydrate }{ }^{\mathrm{L}}\end{array}$ & $\mathrm{CuCl}_{2} \cdot 2 \mathrm{H}_{2} \mathrm{O}$ & $10125-13-0$ & 932 & 2.683 \\
\hline & HP 14 & $\Sigma$ & & Aquatic Chronic 1; H410 & 0.25 & copper sulphate & $\mathrm{CuSO}_{4}$ & $7758-98-7$ & 996 & 2.512 \\
\hline & HP 14 & $\Sigma$ & & Aquatic Chronic $1 ;$ H410 & 0.25 & copper(II) chloride ${ }^{\mathrm{M}}$ & $\mathrm{CuCl}_{2}$ & $7447-39-4$ & 1,182 & 2.116 \\
\hline & HP 14 & $\Sigma$ & HP 12 & Aquatic Chronic $1 ; \mathrm{H} 410$ & 0.25 & copper thiocyanate & CuSCN & $1111-67-7$ & 1,307 & 1.914 \\
\hline & HP 14 & $\Sigma$ & & Aquatic Chronic 1; H410 & 0.25 & $\begin{array}{l}\text { tetracopper hexahydroxide } \\
\text { sulphate }\end{array}$ & $\mathrm{Cu}_{4}(\mathrm{OH})_{6} \mathrm{SO}_{4}$ & $1333-22-8$ & 1,405 & 1.779 \\
\hline & HP 14 & $\Sigma$ & & Aquatic Chronic 1; H410 & 0.25 & $\begin{array}{c}\text { copper(II) carbonate - } \\
\text { copper(II) hydroxide }(1: 1)\end{array}$ & $\mathrm{CuCO}_{3} \cdot \mathrm{Cu}(\mathrm{OH})_{2}$ & $12069-69-1$ & 1,437 & 1.740 \\
\hline & HP 14 & $\Sigma$ & & Aquatic Chronic 1; H410 & 0.25 & $\begin{array}{l}\text { dicopper chloride } \\
\text { trihydroxide }\end{array}$ & $\mathrm{Cu}_{2}(\mathrm{OH})_{3} \mathrm{Cl}$ & $1332-65-6$ & 1,488 & 1.680 \\
\hline & HP 14 & $\Sigma$ & & Aquatic Chronic 1; H410 & 0.25 & copper(I) chloride & $\mathrm{CuCl}$ & $7758-89-6$ & 1,605 & 1.558 \\
\hline & HP 14 & $\Sigma$ & & Aquatic Chronic 1; H410 & 0.25 & copper(II) hydroxide & $\mathrm{Cu}(\mathrm{OH}) 2$ & 20427-59-2 & 1,629 & 1.535 \\
\hline & HP 14 & $\Sigma$ & & Aquatic Chronic 1; H410 & 0.25 & copper(II) oxide & $\mathrm{CuO}$ & $1317-38-0$ & 1,998 & 1.252 \\
\hline & HP 14 & $\Sigma$ & & Aquatic Chronic 1; H410 & 0.25 & copper(I) oxide & $\mathrm{Cu}_{2} \mathrm{O}$ & $1317-39-1$ & 2,221 & 1.126 \\
\hline & HP 14 & $\Sigma$ & & Aquatic Chronic 2; H411 & 2.5 & granulated copper & $\mathrm{Cu}$ & $7440-50-8$ & 25,000 & 1.000 \\
\hline \multirow[t]{2}{*}{$\mathrm{Fe} 026$} & HP 4 & $\Sigma$ & & $\begin{array}{l}\text { Skin Irrit. 2; H315 } \\
\text { Eye Irrit. 2; H319 }\end{array}$ & 20.0 & $\begin{array}{l}\text { iron(II) sulfate } \\
\text { heptahydrate }\end{array}$ & $\mathrm{FeSO}_{4} \cdot 7 \mathrm{H}_{2} \mathrm{O}$ & $7782-63-0$ & 40,177 & 4.978 \\
\hline & HP 4 & $\Sigma$ & & $\begin{array}{l}\text { Skin Irrit. 2; H315 } \\
\text { Eye Irrit. 2; H319 }\end{array}$ & 20.0 & iron(II) sulfate & $\mathrm{FeSO}_{4}$ & $7720-78-7$ & 73,525 & 2.72 \\
\hline \multirow[t]{11}{*}{$\mathrm{Pb} 082$} & HP 7 & $\Sigma$ & & Carc. 1A; H350 & 0.1 & lead hydrogen arsenate & $\begin{array}{l}\mathrm{PbHAsO}_{4} \\
(\text { Note 1) }\end{array}$ & $7784-40-9$ & 1,000 & 1.675 \\
\hline & HP 7 & $\Sigma$ & & Carc. 1B; H350 & 0.1 & $\begin{array}{c}\text { lead chromate molybdate } \\
\text { sulfate; C.I. Pigment } \\
\text { Red } 104\end{array}$ & $\begin{array}{c}\mathrm{PbCrO}_{4^{\prime}} \\
\mathrm{PbMoO}_{4^{\prime}} \\
\mathrm{PbSO}_{4}\left(\mathrm{Note}_{1}\right)\end{array}$ & $12656-85-8$ & 1,000 & 1.560 \\
\hline & HP 7 & $\Sigma$ & & Carc. 1B; H350 & 0.1 & lead chromate & $\begin{array}{l}\mathrm{PbCrO}_{4} \\
(\text { Note 1) }\end{array}$ & $7758-97-6$ & 1,000 & 1.560 \\
\hline & HP 7 & $\Sigma$ & & Carc. 1B; H350 & 0.1 & $\begin{array}{l}\text { lead sulfochromate; C.I. } \\
\text { Pigment Yellow } 34\end{array}$ & $\begin{array}{l}\mathrm{PbCrO}_{4} \\
\mathrm{PbSO}_{4} \\
(\text { Note 1) }\end{array}$ & $1344-37-2$ & 1,000 & 1.511 \\
\hline & HP 7 & $\Sigma$ & & Carc. 1B; H350 & 0.1 & $\begin{array}{l}\text { lead compounds with } \\
\text { the exception of ... (worst } \\
\text { case) }{ }^{N}\end{array}$ & $\begin{array}{c}\text { Pb } \\
(\text { Note 1) }\end{array}$ & - & 1,000 & 1.000 \\
\hline & HP 14 & $\Sigma$ & & Aquatic Chronic 1; H410 & 0.25 & lead di(acetate) ${ }^{\mathrm{N}}$ & $\begin{array}{l}\mathrm{Pb}\left(\mathrm{C}_{2} \mathrm{H}_{3} \mathrm{O}_{2}\right)_{2} \\
\quad(\text { Note1) }\end{array}$ & $301-04-2$ & 2,500 & 1.570 \\
\hline & HP 14 & $\Sigma$ & HP 1 & Aquatic Chronic $1 ;$ H410 & 0.25 & lead azide ${ }^{N}$ & $\begin{array}{l}\mathrm{Pb}\left(\mathrm{N}_{3}\right)_{2} \\
\text { (Note 1) }\end{array}$ & $13424-46-9$ & 2,500 & 1.406 \\
\hline & HP 14 & $\Sigma$ & & Aquatic Chronic 1; H410 & 0.25 & $\begin{array}{l}\text { trilead } \\
\text { bis(orthophosphate) }{ }^{N}\end{array}$ & $\begin{array}{l}\mathrm{Pb}_{3}\left(\mathrm{PO}_{4}\right)_{2} \\
\text { (Note 1) }\end{array}$ & $7446-27-7$ & 2,500 & 1.306 \\
\hline & HP 14 & $\Sigma$ & & Aquatic Chronic $1 ; \mathrm{H} 410$ & 0.25 & $\begin{array}{l}\text { lead compounds with the } \\
\text { exception of those ... }{ }^{N}\end{array}$ & $\begin{array}{c}\mathrm{Pb} \\
\text { (Note 1) }\end{array}$ & - & 2,500 & 1.000 \\
\hline & HP 14 & $\Sigma$ & & Aquatic Chronic $1 ; \mathrm{H} 410$ & 0.25 & lead powder; $<1 \mathrm{~mm}^{\circ}$ & $\mathrm{Pb}$ & $7439-92-1$ & 2,500 & 1.000 \\
\hline & HP 10 & & & Repr. 1A; H360 & 0.30 & lead powder; $\geq 1 \mathrm{~mm}$ & $\mathrm{~Pb}$ & $7439-92-1$ & 3,000 & 1.000 \\
\hline \multirow[t]{3}{*}{ Li 003} & HP 7 & $\Sigma$ & & Carc. 1A; H350 & 0.1 & cobalt lithium nickel oxide & $\mathrm{LiNi}_{0.8} \mathrm{Co}_{0.2} \mathrm{O}_{2}{ }^{\mathrm{P}}$ & - & 72 & 14.066 \\
\hline & HP 3 & $\Sigma$ & & Water-react. $1 ; \mathrm{H} 260^{\mathrm{A}}$ & 0.1 & aluminium lithium hydride & $\mathrm{LiAlH}_{4}$ & $16853-85-3$ & 183 & 5.469 \\
\hline & HP 3 & $\Sigma$ & & Water-react. $1 ; \mathrm{H} 260^{\mathrm{A}}$ & 0.1 & lithium & Li & $7439-93-2$ & 1,000 & 1.000 \\
\hline \multirow[t]{2}{*}{ Mg 012} & HP 6 & $\Sigma$ & & Acute Tox. 1; H330 & 0.1 & magnesium phosphide & $\mathrm{Mg}_{3} \mathbf{P}_{2}$ & $12057-74-8$ & 541 & 1.850 \\
\hline & HP 3 & & HP3(ii) & Water-react. $1 ; \mathrm{H} 260^{\mathrm{A}}$ & 0.1 & magnesium & Mg & $7439-95-4$ & 1,000 & 1.000 \\
\hline
\end{tabular}




\begin{tabular}{|c|c|c|c|c|c|c|c|c|c|c|}
\hline$\sum^{\bar{\pi}}$ & 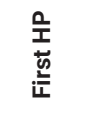 & 竞 & $\begin{array}{l}\text { 율 } \\
\text { 荥 } \\
\text { 옳 }\end{array}$ & $\begin{array}{l}\text { Triggering hazard } \\
\text { statement }\end{array}$ & 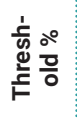 & $\begin{array}{l}\text { Metal species } \\
\text { / CLP entry }\end{array}$ & $\begin{array}{l}\text { Molecular } \\
\text { formula }\end{array}$ & $\begin{array}{l}\text { CAS No. } \\
\text { of CLP } \\
\text { entry }\end{array}$ & $\begin{array}{l}\text { Conc. lim- } \\
\text { it of metal } \\
\mathrm{mg} / \mathrm{kg}\end{array}$ & $\begin{array}{l}\text { Conver. } \\
\text { Factor } \\
\text { (CF) }\end{array}$ \\
\hline & HP 3 & & HP3(iii) & Water-react. 2; H261 A & 0.1 & $\begin{array}{l}\text { magnesium, powder or } \\
\text { turnings }\end{array}$ & Mg & 7439-95-4 & 1,000 & 1.000 \\
\hline & HP 6 & $\Sigma$ & & Acute Tox. 3; H301 & 5.0 & $\begin{array}{c}\text { magnesium } \\
\text { hexafluorosilicate }\end{array}$ & $\mathrm{MgSiF}_{6}$ & $16949-65-8$ & 7,305 & 6.845 \\
\hline \multirow[t]{4}{*}{ Mn 025} & HP 14 & & HP 2 & Aquatic Chronic 1; H410 & 0.25 & potassium permanganate & $\mathrm{KMnO}_{4}$ & $7722-64-7$ & 869 & 2.877 \\
\hline & HP 14 & $\Sigma$ & & Aquatic Chronic 2; H411 & 2.50 & manganese sulphate & $\mathrm{MnSO}_{4}$ & 7785-87-7 & 9,096 & 2.749 \\
\hline & HP 14 & $\Sigma$ & & Aquatic Chronic 1; H411 & 2.50 & manganese(II) chloride ${ }^{Q}$ & $\mathrm{MnCl}_{2}$ & 7773-01-5 & 10,914 & 2.291 \\
\hline & HP 6 & $\Sigma$ & & Acute Tox. 4; H332 & 22.5 & manganese dioxide & $\mathrm{MnO}_{2}$ & 1313-13-9 & 142,185 & 1.582 \\
\hline \multirow[t]{5}{*}{$\mathrm{Hg} 080$} & HP 14 & $\Sigma$ & HP 1 & Aquatic Chronic $1 ; \mathrm{H} 410$ & 0.25 & mercury difulminate & $\mathbf{H g}(\mathrm{CNO})_{2}$ & $628-86-4$ & 1,762 & 1.419 \\
\hline & $\begin{array}{l}\text { HP } 14 \\
\text { HP } 6\end{array}$ & $\Sigma$ & & $\begin{array}{l}\text { Aquatic Chronic } 1 ; \mathrm{H} 410 \\
\text { Acute Tox. } 2^{*} ; \mathrm{H} 300^{\mathrm{R}}\end{array}$ & 0.25 & mercury dichloride & $\mathrm{HgCl}_{2}$ & 7487-94-7 & 1,848 & 1.353 \\
\hline & $\begin{array}{l}\text { HP } 14 \\
\text { HP } 6\end{array}$ & $\Sigma$ & & $\begin{array}{c}\text { Aquatic Chronic } 1 ; \mathrm{H} 410 \\
\text { Acute Tox. 2*; H300 } \\
\text { Acute Tox. 1; H310 }\end{array}$ & 0.25 & $\begin{array}{l}\text { inorganic compounds of } \\
\text { mercury with the exception } \\
\text { of mercuric sulphide and.... }\end{array}$ & $\begin{array}{c}\mathrm{Hg} \\
(\text { Note 1) }\end{array}$ & - & 2,500 & 1.000 \\
\hline & HP 14 & $\Sigma$ & & Aquatic Chronic $1 ; \mathrm{H} 410$ & 0.25 & mercury & $\mathrm{Hg}$ & $7439-97-6$ & 2,500 & 1.000 \\
\hline & HP 12 & & & EUH031 в & 1.0 & mercury(II) sulphide ${ }^{s}$ & $\mathrm{HgS}$ & $1344-48-5$ & 8,622 & 1.160 \\
\hline \multirow[t]{2}{*}{ Mo 042} & HP 7 & $\Sigma$ & & Carc. 1B; H350 & 0.1 & $\begin{array}{l}\text { lead chromate molybdate } \\
\text { sulfate C.I. Pigment Red } \\
104\end{array}$ & $\begin{array}{c}\mathrm{PbCrO}_{4^{\prime}} \\
\mathrm{PbMoO}_{4^{\prime}} \\
\mathrm{PbSO}_{4}(\mathrm{Note} 1)\end{array}$ & $12656-85-8$ & \multicolumn{2}{|c|}{ see lead } \\
\hline & HP 7 & $\Sigma$ & & Carc. 2; H351 & 1.0 & molybdenum trioxide & $\mathrm{MoO}_{3}$ & $1313-27-5$ & 6,666 & 1.500 \\
\hline \multirow[t]{20}{*}{ Ni 028} & HP 7 & $\Sigma$ & & Carc. 1A; H350 & 0.1 & nickel diiodide & $\mathrm{Nil}_{2}$ & $13462-90-3$ & 188 & 5.324 \\
\hline & HP 7 & $\Sigma$ & & Carc. 1A; H350 & 0.1 & nickel dichromate & $\mathrm{NiCr}_{2} \mathrm{O}_{7}$ & $15586-38-6$ & 214 & 4.680 \\
\hline & HP 7 & $\Sigma$ & & Carc. 1A; H350 & 0.1 & nickel dibromide & $\mathrm{NiBr}_{2}$ & 13462-88-9 & 269 & 3.723 \\
\hline & HP 7 & $\Sigma$ & & Carc. 1A; H350 & 0.1 & nickel selenate & $\mathrm{NiSeO}_{4}$ & $15060-62-5$ & \multicolumn{2}{|c|}{ see selenium } \\
\hline & HP 7 & $\Sigma$ & & Carc. 1A; H350 & 0.1 & nickel(II) selenite & $\mathrm{NiSeO}_{3}$ & $10101-96-9$ & \multicolumn{2}{|c|}{ see selenium } \\
\hline & HP 7 & $\Sigma$ & HP 12 & Carc. 1A; H350 & 0.1 & nickel dithiocyanate & $\mathrm{Ni}(\mathrm{SCN})_{2}$ & $13689-92-4$ & 336 & 2.979 \\
\hline & HP 7 & $\Sigma$ & & Carc. 1A; H350 & 0.1 & nickel chromate & $\mathrm{NiCrO}_{4}$ & 14721-18-7 & 336 & 2.976 \\
\hline & HP 7 & $\Sigma$ & & Carc. 1A; H350 & 0.1 & nickel hexacyanoferrate & $\mathrm{Ni}_{2} \mathrm{Fe}(\mathrm{CN})_{6}$ & 14874-78-3 & 357 & 2.806 \\
\hline & HP 7 & $\Sigma$ & & Carc. 1A; H350 & 0.1 & nickel sulfate & $\mathrm{NiSO}_{4}$ & 7786-81-4 & 380 & 2.637 \\
\hline & HP 7 & $\Sigma$ & & Carc. 1A; H350 & 0.1 & nickel selenide & NiSe & $1314-05-2$ & \multicolumn{2}{|c|}{ see selenium } \\
\hline & HP 7 & $\Sigma$ & & Carc. 1A; H350 & 0.1 & nickel dichloride & $\mathrm{NiCl}_{2}$ & 7718-54-9 & 453 & 2.208 \\
\hline & HP 7 & $\Sigma$ & & Carc. 1A; H350 & 0.1 & nickel(II) carbonate & $\mathrm{NiCO}_{3}$ & $3333-67-3$ & 495 & 2.022 \\
\hline & HP 7 & $\Sigma$ & HP 12 & Carc. 1A; H350 & 0.1 & nickel dicyanide & $\mathrm{Ni}(\mathrm{CN})_{2}$ & $557-19-7$ & 531 & 1.887 \\
\hline & HP 7 & $\Sigma$ & & Carc. 1A; H350 & 0.1 & nickel difluoride & $\mathrm{NiF}_{2}$ & $10028-18-9$ & 608 & 1.647 \\
\hline & HP 7 & $\Sigma$ & & Carc. 1A; H350 & 0.1 & nickel dihydroxide & $\mathrm{Ni}(\mathrm{OH})_{2}$ & $\begin{array}{l}12054-48-7 \\
11113-74-9\end{array}$ & 634 & 1.579 \\
\hline & HP 7 & $\Sigma$ & & Carc. 1A; H350 & 0.1 & nickel sulphide & $\mathrm{NiS}$ & $16812-54-7$ & 647 & 1.546 \\
\hline & HP 7 & $\Sigma$ & & Carc. 1A; H350 & 0.1 & $\begin{array}{c}\text { nickel dioxide; nickel(IV) } \\
\text { oxide; }\end{array}$ & $\mathrm{NiO}_{2}$ & $12035-36-8$ & 648 & 1.545 \\
\hline & HP 7 & $\Sigma$ & & Carc. 1A; H350 & 0.1 & dinickel trioxide & $\mathrm{Ni}_{2} \mathrm{O}_{3}$ & $1314-06-3$ & 710 & 1.409 \\
\hline & HP 7 & $\Sigma$ & & Carc. 1A; H350 & 0.1 & $\begin{array}{c}\text { nickel monoxide; nickel(II) } \\
\text { oxide }\end{array}$ & $\mathrm{NiO}$ & 1313-99-1 & 786 & 1.273 \\
\hline & $\begin{array}{l}\text { HP } 7 \\
\text { HP } 5\end{array}$ & $\Sigma$ & & $\begin{array}{c}\text { Carc. 2; H351 } \\
\text { STOT RE 1; H372 }\end{array}$ & 1.0 & nickel & $\mathrm{Ni}$ & $7440-02-0$ & 10,000 & 1.000 \\
\hline \multirow[t]{4}{*}{ K 019} & HP 7 & $\Sigma$ & HP 2 & Carc. 1B; H350 & 0.1 & potassium bromate & $\mathrm{KBrO}_{3}$ & 7758-01-2 & 235 & 4.271 \\
\hline & $\begin{array}{l}\text { HP } 7 \\
\text { HP } 11\end{array}$ & $\Sigma$ & HP 2 & $\begin{array}{l}\text { Carc. 1B; H350 } \\
\text { Muta. 1B; H340 }\end{array}$ & 0.1 & potassium dichromate & $\mathrm{K}_{2} \mathrm{Cr}_{2} \mathrm{O}_{7}$ & $7778-50-9$ & 266 & 3.762 \\
\hline & $\begin{array}{l}\text { HP } 7 \\
\text { HP } 11\end{array}$ & $\Sigma$ & & $\begin{array}{l}\text { Carc. 1B; H350 } \\
\text { Muta. 1B; H340 }\end{array}$ & 0.1 & potassium chromate & $\mathrm{K}_{2} \mathrm{CrO}_{4}$ & $7789-00-6$ & 403 & 2.483 \\
\hline & HP 14 & $\Sigma$ & HP 2 & Aquatic Chronic 1; H410 & 0.25 & potassium permanganate & $\mathrm{KMnO}_{4}$ & $7722-64-7$ & \multicolumn{2}{|c|}{ see manganese } \\
\hline
\end{tabular}




\begin{tabular}{|c|c|c|c|c|c|c|c|c|c|c|}
\hline 嵒 & 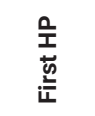 & 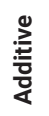 & 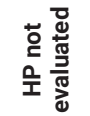 & $\begin{array}{l}\text { Triggering hazard } \\
\text { statement }\end{array}$ & 童 & $\begin{array}{l}\text { Metal species } \\
\text { / CLP entry }\end{array}$ & $\begin{array}{c}\text { Molecular } \\
\text { formula }\end{array}$ & $\begin{array}{l}\text { CAS No. } \\
\text { of CLP } \\
\text { entry }\end{array}$ & $\begin{array}{l}\text { Conc. lim- } \\
\text { it of metal } \\
\mathrm{mg} / \mathrm{kg}\end{array}$ & $\begin{array}{l}\text { Conver. } \\
\text { Factor } \\
\text { (CF) }\end{array}$ \\
\hline & HP 12 & $\Sigma$ & & EUH031 ${ }^{\mathrm{B}}$ & 0.5 & potassium sulphide & $\mathrm{K}_{2} \mathrm{~S}$ & $1312-73-8$ & 3,546 & 1.410 \\
\hline & HP 3 & $\Sigma$ & & Water-react. $1 ; \mathrm{H} 26 \mathrm{O}^{\mathrm{A}}$ & 0.4 & potassium & K & $7440-09-7$ & 4,000 & 1.000 \\
\hline & HP 4 & $\Sigma$ & & Skin Corr. 1A; H314 & 1.0 & potassium hydroxide & $\mathrm{KOH}$ & 1310-58-3 & 6,969 & 1.435 \\
\hline & HP 14 & $\Sigma$ & HP 2 & Aquatic Chronic 2; H411 & 2.5 & potassium chlorate & $\mathrm{KClO}_{3}$ & $3811-04-9$ & 7,977 & 3.134 \\
\hline & HP 8 & $\Sigma$ & & Skin Corr. 1B; H314 & 5.0 & $\begin{array}{l}\text { potassium hydrogen } \\
\text { sulphate }\end{array}$ & $\mathrm{KHSO}_{4}$ & $7646-93-7$ & 14,357 & 3.483 \\
\hline & HP 6 & $\Sigma$ & HP 2 & Acute Tox. 3; H301 & 5.0 & potassium nitrite & $\mathrm{KNO}_{2}$ & $7758-09-0$ & 22,971 & 2.177 \\
\hline & HP 6 & $\Sigma$ & & Acute Tox. $3 ;$ H331 & 3.5 & potassium fluoride & $\mathrm{KF}$ & $7789-23-3$ & 23,555 & 1.486 \\
\hline & $\begin{array}{l}\text { HP } 6 \\
\text { HP } 8\end{array}$ & $\Sigma$ & & $\begin{array}{l}\text { Acute Tox. 3; H301 } \\
\text { Skin Corr. 1B; H314 }\end{array}$ & 5.0 & potassium bifluoride & $\mathrm{KHF}_{2}$ & $7789-29-9$ & 25,031 & 1.998 \\
\hline & HP 6 & $\Sigma$ & HP 2 & Acute Tox. $4 ; \mathrm{H} 302$ & 25.0 & potassium perchlorate & $\mathrm{KClO}_{4}$ & $7778-74-7$ & 70,550 & 3.544 \\
\hline & HP 6 & $\Sigma$ & & Acute Tox. 4; H302 & 25.0 & potassium cyanate & KCNO & $590-28-3$ & 120,503 & 2.075 \\
\hline \multirow[t]{12}{*}{ P 015} & HP 12 & $\Sigma$ & HP 3 & EUH029 в & 0.1 & phosphorus pentasulfide & $\mathbf{P}_{2} \mathrm{~S}_{5}$ & $1314-80-3$ & 279 & 3.588 \\
\hline & HP 6 & $\Sigma$ & HP 12 & Acute Tox. 2; H300 & 0.25 & phosphorous trichloride & $\mathrm{PCl}_{3}$ & $7719-12-2$ & 564 & 4.434 \\
\hline & HP 6 & $\Sigma$ & HP 12 & Acute Tox. 2; H330 & 0.5 & phosphorous pentachloride & $\mathrm{PCl}_{5}$ & $10026-13-8$ & 744 & 6.723 \\
\hline & HP 6 & $\Sigma$ & HP 12 & Acute Tox. 2; H330 & 0.5 & phosphoryl trichloride & $\mathrm{POCl}_{3}$ & $10025-87-3$ & 1,011 & 4.950 \\
\hline & HP 6 & $\Sigma$ & HP 3 & Acute Tox. 2; H30O & 0.25 & white phosphorous & $\mathbf{P}_{4}$ & $12185-10-3$ & 2,500 & 1.000 \\
\hline & HP 4 & $\Sigma$ & & Skin Corr. 1A; H314 & 1.0 & $\begin{array}{l}\text { phosphonic acid; phospho- } \\
\text { rous acid }\end{array}$ & $\mathrm{H}_{3} \mathrm{PO}_{3}$ & $\begin{array}{l}13598-36-2 \\
10294-56-1\end{array}$ & 3,778 & 2.647 \\
\hline & HP 4 & $\Sigma$ & & Skin Corr. 1A; H314 & 1.0 & phosphorous pentoxide & $\mathbf{P}_{4} \mathrm{O}_{10}$ & $1314-56-3$ & 4,365 & 2.291 \\
\hline & HP 6 & $\Sigma$ & HP 3 & Acute Tox. 2; H330 & 0.5 & phosphine & $\mathrm{PH}_{3}$ & $7803-51-2$ & 4,556 & 1.098 \\
\hline & HP 8 & $\Sigma$ & & Skin Corr. 1B; H314 & 5.0 & phosphorous tribromide & $\mathrm{PBr}_{3}$ & $7789-60-8$ & 5,722 & 8.739 \\
\hline & HP 8 & $\Sigma$ & & Skin Corr. 1B; H314 & 5.0 & phosphoric acid & $\mathrm{H}_{3} \mathrm{PO}_{4}$ & $7664-38-2$ & 15,804 & 3.164 \\
\hline & $\begin{array}{l}\text { HP } 6 \\
\text { HP } 14\end{array}$ & $\Sigma$ & HP 3 & $\begin{array}{c}\text { Acute Tox. 4; } \mathrm{H} 302 \\
\text { Aquatic Acute } 1 ; \mathrm{H} 400\end{array}$ & 25.0 & $\begin{array}{l}\text { tetraphosphorus } \\
\text { trisulphide; phosphorus } \\
\text { sesquisulphid }\end{array}$ & $\mathbf{P}_{4} \mathrm{~S}_{3}$ & $1314-85-8$ & 140,731 & 1.776 \\
\hline & HP 14 & $\Sigma$ & HP 3 & Aquatic Chronic $3 ; \mathrm{H} 412$ & 25.0 & red phosphorous & $\mathbf{P}$ & $7723-14-0$ & 250,000 & 1.000 \\
\hline \multirow[t]{6}{*}{ Se 034} & HP 7 & $\Sigma$ & & Carc. 1A; H350 & 0.1 & nickel selenate & $\mathrm{NiSeO}_{4}$ & $15060-62-5$ & 392 & 2.554 \\
\hline & $\mathrm{HP} 7$ & $\Sigma$ & & Carc. 1A; H350 & 0.1 & nickel(II) selenite & $\mathrm{NiSeO}_{3}$ & $10101-96-9$ & 425 & 2.351 \\
\hline & HP 7 & $\Sigma$ & & Carc. 1A; H350 & 0.1 & nickel selenide & NiSe & $1314-05-2$ & 574 & 1.743 \\
\hline & HP 6 & $\Sigma$ & HP 12 & Acute Tox. 2; H300 & 0.25 & sodium selenite & $\mathrm{Na}_{2} \mathrm{SeO}_{3}$ & $10102-18-8$ & 1,142 & 2.190 \\
\hline & HP 14 & $\Sigma$ & & Aquatic Chronic $1 ; \mathrm{H} 410$ & 0.25 & $\begin{array}{l}\text { selenium compounds with } \\
\text { the exception of those ... }\end{array}$ & Se as $\mathrm{SeO}_{2}$ & - & 1,779 & 1.405 \\
\hline & HP 6 & $\Sigma$ & & Acute Tox. 3; H331 & 3.5 & selenium & Se & $7782-49-2$ & 35,000 & 1.000 \\
\hline Ag 047 & HP 14 & $\Sigma$ & HP 2 & Aquatic Chronic 1; H410 & 0.25 & silver nitrate & $\mathrm{AgNO}_{3}$ & 7761-88-8 & 1,588 & 1.575 \\
\hline \multirow[t]{11}{*}{$\mathrm{Na} 011$} & $\begin{array}{l}\text { HP } 7 \\
\text { HP } 11\end{array}$ & $\Sigma$ & HP 2 & $\begin{array}{l}\text { Carc. 1B; H350 } \\
\text { Muta. 1B; H340 }\end{array}$ & 0.1 & sodium dichromate & $\mathrm{Na}_{2} \mathrm{Cr}_{2} \mathrm{O}_{7}$ & 10588-01-9 & 176 & 5.698 \\
\hline & $\begin{array}{l}\text { HP } 7 \\
\text { HP } 11\end{array}$ & $\Sigma$ & & $\begin{array}{l}\text { Carc. 1B; H350 } \\
\text { Muta. 1B; H340 }\end{array}$ & 0.1 & sodium chromate & $\mathrm{Na}_{2} \mathrm{CrO}_{4}$ & $7775-11-3$ & 284 & 3.523 \\
\hline & HP 6 & $\Sigma$ & & $\begin{array}{l}\text { Acute Tox. } 2 ; \mathrm{H} 300 \\
\text { Acute Tox. } 1 ; \mathrm{H} 310\end{array}$ & 0.25 & sodium fluoroacetate & $\mathrm{NaFCH}_{2} \mathrm{CO}_{2}$ & $62-74-8$ & 575 & 4.351 \\
\hline & HP 14 & $\Sigma$ & & Aquatic Chronic $1 ; \mathrm{H} 410$ & 0.25 & sodium hypochlorite & $\mathrm{NaClO}$ & $7681-52-9$ & 773 & 3.238 \\
\hline & HP 3 & & & Water-react. $1 ; \mathrm{H} 260^{\mathrm{A}}$ & 0.1 & sodium hydride & $\mathrm{NaH}$ & $7646-69-7$ & 959 & 1.044 \\
\hline & HP 12 & $\Sigma$ & & EUH032 ${ }^{\mathrm{B}}$ & 0.2 & sodium fluoride & $\mathrm{NaF}$ & $7681-49-4$ & 1,096 & 1.826 \\
\hline & HP 3 & $\Sigma$ & & Water-react. $1 ; \mathrm{H} 260^{\mathrm{A}}$ & 0.2 & sodium & $\mathrm{Na}$ & $7440-23-5$ & 2,000 & 1.000 \\
\hline & HP 12 & $\Sigma$ & HP 3 & EUH031 в & 0.9 & $\begin{array}{l}\text { sodium dithionite; sodium } \\
\text { hydrosulphite }\end{array}$ & $\mathrm{Na}_{2} \mathrm{~S}_{2} \mathrm{O}_{4}$ & $7775-14-6$ & 2,377 & 3.787 \\
\hline & HP 14 & $\Sigma$ & HP 2 & Aquatic Chronic 2; H411 & 2.5 & sodium chlorate & $\mathrm{NaClO}_{3}$ & 7775-09-9 & 5,400 & 4.630 \\
\hline & $\mathrm{HP} 4$ & $\Sigma$ & & Skin Corr. 1A; H314 & 1.0 & $\begin{array}{l}\text { sodium hydroxide; caustic } \\
\text { soda }\end{array}$ & $\mathrm{NaOH}$ & $1310-73-2$ & 5,748 & 1.740 \\
\hline & HP 4 & $\Sigma$ & HP 2 & Skin Corr. 1A; H314 & 1.0 & sodium peroxide & $\mathrm{Na}_{2} \mathrm{O}_{2}$ & $1313-60-6$ & 5,897 & 1.696 \\
\hline
\end{tabular}




\begin{tabular}{|c|c|c|c|c|c|c|c|c|c|c|}
\hline$\sum_{\Sigma}^{\bar{d}}$ & 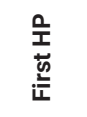 & 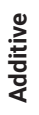 & 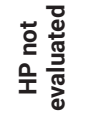 & $\begin{array}{l}\text { Triggering hazard } \\
\text { statement }\end{array}$ & 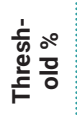 & $\begin{array}{l}\text { Metal species } \\
\text { / CLP entry }\end{array}$ & $\begin{array}{l}\text { Molecular } \\
\text { formula }\end{array}$ & $\begin{array}{l}\text { CAS No. } \\
\text { of CLP } \\
\text { entry }\end{array}$ & $\begin{array}{l}\text { Conc. lim- } \\
\text { it of metal } \\
\mathrm{mg} / \mathbf{k g}\end{array}$ & $\begin{array}{c}\text { Conver. } \\
\text { Factor } \\
\text { (CF) }\end{array}$ \\
\hline & HP 6 & $\Sigma$ & HP 2 & Acute Tox. 3; H301 & 5.0 & sodium nitrite & $\mathrm{NaNO}_{2}$ & $7632-00-0$ & 16,661 & 3.001 \\
\hline & HP 4 & $\Sigma$ & & Eye Dam. 1; H318 & 10.0 & sodium hydrogensulphate & $\mathrm{NaHSO}_{3}$ & $7631-90-5$ & 19,149 & 5.222 \\
\hline & HP 4 & $\Sigma$ & HP 12 & Eye Dam. 1; H318 & 10.0 & sodium metabisulphite & $\mathrm{Na}_{2} \mathrm{~S}_{2} \mathrm{O}_{5}$ & $7681-57-4$ & 24,186 & 4.135 \\
\hline & HP 6 & $\Sigma$ & HP 12 & Acute Tox. 4; H302 & 25.0 & $\begin{array}{c}\text { sodium hydrogensulphite ... } \\
\% ; \text { sodium bisulphite ... \% }\end{array}$ & $\mathrm{NaHSO}_{3}$ & $7631-90-5$ & 55,231 & 4.526 \\
\hline & HP 6 & $\Sigma$ & HP 2 & Acute Tox. 4; $\mathrm{H} 302$ & 25.0 & sodium perchlorate & $\mathrm{NaClO}_{4}$ & 7601-89-0 & 77,206 & 3.238 \\
\hline Sr 038 & HP 7 & $\Sigma$ & & Carc. 1B; H350 & 0.1 & strontium chromate & $\mathrm{SrCrO}_{4}$ & $7789-06-2$ & 431 & 2.324 \\
\hline \multirow[t]{3}{*}{ S 016} & HP 8 & $\Sigma$ & & Skin Corr. 1B; H314 & 5.0 & sulphur dichloride & $\mathbf{S C l}_{2}$ & $10545-99-0$ & 15,570 & 3.211 \\
\hline & HP 6 & $\Sigma$ & & Acute Tox. 3; H331 & 3.5 & sulphur dioxide & $\mathrm{SO}_{2}$ & $7446-09-5$ & 17,519 & 1.998 \\
\hline & HP 4 & $\Sigma$ & & Skin Irrit. 2; H315 & 20.0 & sulfur & s & $7704-34-9$ & 200,000 & 1.000 \\
\hline \multirow[t]{4}{*}{ TI 081} & HP 7 & $\Sigma$ & & Carc. 1A; H350 & 0.1 & $\begin{array}{l}\text { thallium compounds with } \\
\text { the exception of those } . .\end{array}$ & $\begin{array}{c}\text { TI as } \mathrm{Tl}_{2} \mathrm{CrO}_{4} \\
\text { as } \mathrm{Tl}_{2} \mathrm{O}_{3}\end{array}$ & - & $\begin{array}{l}779 \\
895\end{array}$ & $\begin{array}{l}1.284 \\
1.117\end{array}$ \\
\hline & HP 6 & $\Sigma$ & & Acute Tox. 2; H30O & 0.25 & thallium thiocyanate & TISCN & $3535-84-0$ & 1,947 & 1.284 \\
\hline & HP 6 & $\Sigma$ & & Acute Tox. 2; H300 & 0.25 & $\begin{array}{l}\text { dithallium sulphate; thallic } \\
\text { sulphate }\end{array}$ & $\mathrm{TI}_{2} \mathrm{SO}_{4}$ & $7446-18-6$ & 2,025 & 1.235 \\
\hline & HP 6 & $\Sigma$ & & Acute Tox. 2; $\mathrm{H} 300$ & 0.25 & thallium & TI & $7440-28-0$ & 2,500 & 1.000 \\
\hline \multirow[t]{2}{*}{ Ti 022} & $\mathrm{HP} 7$ & & & Carc. 2; H351 & 1.0 & titanium dioxide & $\mathrm{TiO}_{2}$ & $13463-67-7$ & 5,994 & 1.668 \\
\hline & HP 8 & $\Sigma$ & & Skin Corr. 1B; H314 & 5.0 & titanium tetrachloride & $\mathrm{TiCl}_{4}$ & $7550-45-0$ & 12,618 & 3.963 \\
\hline \multirow[t]{3}{*}{ Sn 050} & HP 14 & $\Sigma$ & & Aquatic Chronic $1 ; \mathrm{H} 410$ & 0.25 & $\begin{array}{l}\text { tributyltin compounds with } \\
\text { the exception of those ... }\end{array}$ & $\begin{array}{l}\mathrm{Sn}\left(\mathrm{C}_{4} \mathrm{H}_{9}\right)_{3} \\
(\text { Note 1) }\end{array}$ & - & 2,500 & 1.000 \\
\hline & HP 14 & $\Sigma$ & & Aquatic Chronic 2; H411 & 2.5 & tin(II) methanesulphonate & $\mathrm{Sn}\left(\mathrm{CH}_{3} \mathrm{SO}_{3}\right)_{2}$ & $53408-94-9$ & 9,608 & 2.602 \\
\hline & HP 8 & $\Sigma$ & & Skin Corr. 1B; H314 & 5.0 & $\begin{array}{l}\text { tin tetrachloride; stannic } \\
\text { chloride }\end{array}$ & $\mathrm{SnCl}_{4}$ & $7646-78-8$ & 22,784 & 2.195 \\
\hline \multirow[t]{3}{*}{ U 092} & HP 7 & & & Carc. 1A; H350 & 0.1 & nickel triuranium decaoxide & $\mathrm{NiU}_{3} \mathrm{O}_{10}$ & $15780-33-3$ & 766 & 1.306 \\
\hline & HP 6 & $\Sigma$ & & Acute Tox. 2; H300 & 0.25 & $\begin{array}{l}\text { uranium compounds with } \\
\text { the exception of those ... }\end{array}$ & $\mathbf{U}$ as $\mathrm{UO}_{2}$ & - & 2,204 & 1.134 \\
\hline & HP 6 & $\Sigma$ & & Acute Tox. 2; H300 & 0.25 & uranium & $\mathbf{U}$ & $7440-61-1$ & 2,500 & 1.000 \\
\hline V 023 & $\begin{array}{l}\text { HP } 5 \\
\text { HP } 11\end{array}$ & $\Sigma$ & & $\begin{array}{l}\text { STOT RE } 1 ; \mathrm{H} 372 \\
\text { Muta. } 2 ; \mathrm{H} 341\end{array}$ & 1.0 & vanadium pentoxide & $\mathbf{v}_{2} \mathrm{O}_{5}$ & $1314-62-1$ & 5,602 & 1.785 \\
\hline \multirow[t]{9}{*}{ Zn 030} & $\mathrm{HP} 7$ & $\Sigma$ & & Carc. 1A; H350 & 0.1 & zinc chromate & $\mathrm{ZnCrO}_{4}$ & $13530-65-9$ & 361 & 2.774 \\
\hline & HP 14 & $\Sigma$ & & Aquatic Chronic $1 ; \mathrm{H} 410$ & 0.25 & $\begin{array}{l}\text { zinc sulphate } \\
\text { heptahydrate }^{\top}\end{array}$ & $\mathrm{ZnSO}_{4} \cdot 7 \mathrm{H}_{2} \mathrm{O}$ & $7446-20-0$ & 568 & 4.398 \\
\hline & HP 14 & $\Sigma$ & & Aquatic Chronic $1 ; \mathrm{H} 410$ & 0.25 & $\begin{array}{l}\text { zinc sulphate } \\
\text { monohydrate }{ }^{\top}\end{array}$ & $\mathrm{ZnSO}_{4} \cdot 1 \mathrm{H}_{2} \mathrm{O}$ & $7446-19-7$ & 911 & 2.745 \\
\hline & HP 14 & $\Sigma$ & & Aquatic Chronic $1 ; \mathrm{H} 410$ & 0.25 & zinc sulphate (anhydrous) $^{\top}$ & $\mathrm{ZnSO}_{4}$ & $7733-02-0$ & 1,013 & 2.469 \\
\hline & HP 14 & $\Sigma$ & & Aquatic Chronic $1 ; \mathrm{H} 410$ & 0.25 & zinc chloride & $\mathrm{ZnCl}_{2}$ & $7646-85-7$ & 1,200 & 2.085 \\
\hline & HP 14 & $\Sigma$ & & Aquatic Chronic $1 ; \mathrm{H} 410$ & 0.25 & trizinc bis(orthophosphate) & $\mathrm{Zn}_{3}\left(\mathrm{PO}_{4}\right)_{2}$ & $7779-90-0$ & 1,271 & 1.968 \\
\hline & $\begin{array}{l}\operatorname{HP} 14 \\
\operatorname{HP} 6\end{array}$ & $\begin{array}{l}\Sigma \\
\Sigma\end{array}$ & & $\begin{array}{c}\text { Aquatic Chronic } 1 ; \mathrm{H} 410 \\
\text { Acute Tox. 2; H300 }\end{array}$ & 0.25 & $\begin{array}{l}\text { trizinc diphosphide; zinc } \\
\text { phosphide }\end{array}$ & $\mathrm{Zn}_{3} \mathbf{P}_{2}$ & $1314-84-7$ & 1,900 & 1.316 \\
\hline & HP 14 & $\Sigma$ & & Aquatic Chronic $1 ; \mathrm{H} 410$ & 0.25 & zinc oxide & $\mathrm{ZnO}$ & $1314-13-2$ & 2,009 & 1.245 \\
\hline & HP 14 & $\Sigma$ & HP 3 & Aquatic Chronic $1 ; \mathrm{H} 410$ & 0.25 & zinc powder & $\mathrm{Zn}$ & $7440-66-6$ & 2,500 & 1.000 \\
\hline
\end{tabular}

\section{Key}

Substance not in CLP - data source(s) in footnote: self-classification

Modified CLP substance - explanation in footnote

\section{General Notes}

1. Tables 2 and 3 were compiled in autumn 2020. Moving forwards, knowledge about substances changes and therefore both the ranking and the triggering hazard property published in these tables may change as updated information is published, either through ATPs or through self-classifications that find evidence for missing hazard classes.

2. The CLP hasn't been consistent in its naming conventions; so for example, sulfate and sulphate are both in common usage in the data set. The use of oxidation numbers is also inconsistent e.g. and copper sulphate and copper(II) oxide.

3. While sulfur (S) has been speciated, typically the laboratory concentration a classifier receives reflects the sulfur present in anions such as sulfates, sulfides and thiocyanates. For some waste streams, it could also be reflecting the sulfur present in natural organosulfur compounds such as amino acids or thiophene found in coal tars. 


\section{Table Footnotes}

A. HP 3 - H260 and H261 were also assessed based on calculation methods: WM3 (2018) Table C3.2 and EU (2018) Table 11

B. HP 12 - EUH029, EUH031 and EUH032 were also assessed based on calculation methods: WM3 (2018) Table C12.2 and EU (2018) Table 21

C. IARC (2020) considers these compounds to be Group 1 Carcinogenic to humans; H350 Carc. 1A added

D. IARC (2020) considers these compounds to be Group 1 Carcinogenic to humans; H350 Carc. 1B added

E. Data sources: C\&L (2020), worst case

F. Data sources: Sigma Aldrich, 2020: SDS barium chromate, version 6.2, dated 08.05.2020; C\&L (2020)

G. Data sources: Sigma Aldrich, 2020: SDS barium oxide, version 6.0, dated 06.02.2020; C\&L (2020)

H. Data sources: Sigma Aldrich, 2020: SDS barium sulfate, version 6.1, dated 15.04.2020; C\&L (2020)

I. Data sources: Sigma Aldrich, 2019: SDS beryllium chloride, version 6.0, dated 24.10.2019; C\&L (2020)

J. Data sources: Sigma Aldrich, 2020 SDS calcium hydroxide, version 6.0, dated 10.02.2020; C\&L (2020) EU (2018)

K. Data sources: Sigma Aldrich, 2019 SDS calcium oxide, version 6.0, dated 24.10.2019; C\&L (2020) EU (2018)

L. Data sources: Sigma Aldrich, 2019 SDS copper(II) chloride dihydrate, version 6.0, dated 24.10.2019; C\&L (2020)

M. Data sources: Sigma Aldrich, 2019 SDS copper(II) chloride, version 6.0, dated 24.10.2019; C\&L (2020)

N. The CLP entry for "lead compounds" does not have an entry for HP 7 carcinogenic. IARC (2020) considers all lead compounds to be "Group 2A - Probably carcinogenic to humans". For hazard classes not covered by Annex VI of the CLP, the manufacturer or importer is required to self-classify the substance in accordance with the CLP criteria. The Lead REACH Consortium (https://ila-reach.org/) compared the IARC approach to the CLP approach and concluded that most common lead compounds (oxides, chlorides sulphates etc.) should be Carc. 2; H351 (Lead REACH Consortium (2015a)), while only those lead compounds from smelting industries and flue dust should be worst case Carc. $1 \mathrm{~A} ; \mathrm{H} 350$.

O. Self-classification; Lead Reach Consortium (2015b), Substance grade data sheet dated October 2017

P. Formula source: lithium nickel cobalt oxide, CAS 113066-89-0 www.sigmaaldrich.com SDS accessed 29 May 2020; no molecular formula or CAS listed in ECHA (C\&L 2020)

Q. Data sources: Sigma Aldrich, 2019 SDS manganese(II) chloride, version 6.0, dated 05.10.2019; C\&L (2020)

R. Acute Tox. 2* H300: Minimum entry confirmed by Sigma Aldrich 2019: SDS mercury(II) chloride, version 6.0, dated 24.10.2019; C\&L (2020)

S. Data sources: Sigma Aldrich, 2019 SDS mercury(II) sulfide red, version 6.0, dated 17.09.2019; C\&L (2020)

T. The actual CLP entry is: zinc sulphate (hydrous) (mono-, hexa- and hepta hydrate) [1]; zinc sulphate (anhydrous) [2]

Evidence can include information discovered by the desktop study, observations from investigations, SDS for chemicals used in industrial processes, use of existing laboratory test results and optimization of further laboratory testing, combined with an understanding of some basic chemistry to achieve a more reasonable case. If not already commissioned, further laboratory testing can include measuring the leachable concentrations of key cations and anions and information on the physico-chemical status of the waste including $\mathrm{pH}$, acid/alkali reserve and redox potential.

In the example discussed below, all the metadata, including typical uses of the substances, chemical formulas and chemical properties, like solubility, can be found using Google, Wikipedia or the HazWasteOnline ${ }^{\mathrm{TM}}$ Wiki, with support from reference books such as CRC (2020). Note also that the example below is simplified to a single sample result and one metal and does not assess all the other determinands. It also does not attempt to further justify decisions based on the analysis of a suitable sample population or statistical analysis. Appendix D of WM3 (2018) discusses these aspects in more detail.

The scenario is a builder's yard that is going to be redeveloped, with contaminated soils removed for disposal to a waste management facility. Prior to the use by the builder, the site was a field used for agriculture. A site walkover found evidence for the burning of waste wood and also steel belts resulting from the combustion of car tyres. Empty aerosol cans containing lead oxide and zinc oxide primer were also observed. Finally, no evidence was found for the presence of zinc compounds that are not already listed in Table 3.

Laboratory testing included ten heavy metals, total petroleum hydrocarbons, the standard 16 PAHs and moisture, plus the anions: sulphate, phosphate and chloride. With respect to zinc, analysis of a one soil sample found a (dry weight) concentration of $3,000 \mathrm{mg} / \mathrm{kg}$.

Focusing on the selection of a reasonable worst case species for zinc, the exercise will start from the worst case zinc species, zinc chromate and work down the listings in Table 3.
All chromates (i.e. the anion, $\mathrm{CrO}_{4}^{2-}$ and dichromates, $\mathrm{Cr}_{2} \mathrm{O}_{7}{ }^{2-}$ ) are HP 7 Carcinogenic at compound concentrations of $0.1 \%$ or $1,000 \mathrm{mg} / \mathrm{kg}$. The chromium in chromates in known as chromium( $\mathrm{VI})$ or hexavalent chromium due to its oxidation state. If total chromium is measured by the laboratory, this includes both common oxidation states of chromium, namely chromium(III) and chromium(VI). Stoichiometrically, $3,000 \mathrm{mg} / \mathrm{kg}$ of total zinc equates to 8,322 $\mathrm{mg} / \mathrm{kg}$ of zinc chromate (CF=2.774), of which $2,386 \mathrm{mg} / \mathrm{kg}$ would be chromium(VI). In this example, only total chromium was measured, the result being $30 \mathrm{mg} / \mathrm{kg}$. Assuming the worst case and thus the measured chromium is all in the form of chromium( $(\mathrm{VI})$, it is clear that there is nowhere near enough chromium to make $8,322 \mathrm{mg} / \mathrm{kg}$ of zinc chromate. $(30 \mathrm{mg} / \mathrm{kg}$ of chromium(VI) limits the amount of zinc chromate to only $105 \mathrm{mg} / \mathrm{kg}$, which is far below the hazardous threshold.)

A more thorough test to confirm that there are no chromates of, for example, zinc, nickel and lead, is to test for speciated chromium(VI) (EN 15192) and for total chromium, the difference being chromium(III).

Both of the above arguments can be used to justify discounting the worst case zinc compound and moving to the next worse case metal species in the list.

Zinc sulphate and zinc chloride (and their hydrous forms) will be discussed together as all are soluble compounds. The lines of evidence are:

- No evidence for the use of zinc chloride or zinc sulphate on the site.

- $\mathrm{ZnSO}_{4}$ (and hydrous forms) and $\mathrm{ZnCl}_{2}$ are both more soluble than table salt $\left(577 \mathrm{~g} / \mathrm{l}\right.$ and $4,320 \mathrm{~g} / \mathrm{l}\left(25^{\circ} \mathrm{C}\right)$ respectively (CRC 2020)).

- The soil has been exposed to the elements and the water table for some significant period, so these compounds are unlikely to be present, if they were ever there.

With respect to the last bullet, if there was evidence for the presence of either of these two compounds, the leach- 
ing away argument would not be enough to justify removing them from consideration. However, the argument can be strengthened by two further chemical test solutions.

The first is including laboratory tests for soluble sulphates and chlorides. If there are no soluble sulphates or chlorides or the concentrations that are measured limit the amounts of these species, then this can be used as evidence that these species can be discounted. However, these results can be inconclusive as sulphates and chlorides can be related to other inorganic compounds potentially present in a builder's yard or soils, for example, plaster is calcium sulphate dihydrate.

The best supporting evidence is to consider including an eluate test; i.e. a measure of any soluble metals at the $\mathrm{pH}$ of the material, as in EN 12457-2. If this test shows no soluble zinc for example, then that rules out both zinc sulphate and zinc chloride and their hydrated forms. Note that for zinc, this information can also be found in the WAC test, so the classifier may already have the extra evidence.

Zinc phosphate, $\left(\mathrm{Zn}_{3}\left(\mathrm{PO}_{4}\right)_{2}\right)$ is the next in the list. Note that CLP Table 3 calls it trizinc bis(orthophosphate). It is used in corrosion resistant coatings, putties and fillers and is insoluble in water. If this compound were present in the builder's yard, we would expect 2,905 mg/kg of orthophosphate in the laboratory results. In this example, the laboratory only measured $30 \mathrm{mg} / \mathrm{kg}$ of orthophosphates so this compound can also be discounted.

The next suspect is zinc phosphide, $\mathrm{Zn}_{3} \mathrm{P}_{2}$. The substance is used in products like photovoltaic cells and rodenticides, neither of which has been used on the site. If you look at the metadata for this compound, either in $\mathrm{Ha}$ $z_{\text {WasteOnline }}{ }^{\mathrm{TM}}$ or the entry in CLP Table 3, this substance has six hazard statements including EUH029 Contact with water liberates toxic gas. As the site is not arid and subject to rainfall/water table; if this material was ever present, it has long since reacted with water to generate zinc hydroxide and the flammable gas, phosphine.

So zinc phosphide can be ruled out.

The next worst case is zinc oxide, $\mathrm{ZnO}$ which is used in both car tyres and paints, both entities identified on site. Zinc oxide is virtually insoluble in water at $\mathrm{pH} 7$ (CRC 2020), so won't be leached away.

With the evidence available, zinc oxide is the most reasonable worst case zinc species to use in the classification of these contaminated soils. It would trigger HP 14 Ecotoxic.

\section{CONCLUSIONS}

A complete set of more than two hundred worst case to less worst case metal species, for thirty two elements, is now available for use in the hazardous waste classification of mixtures. The list includes harmonised entries from Annex VI, Table 3 of the CLP (equivalent to the mandatory entries in the United Kingdom's GB CLP Regulation (UK 2018, $2019,2020)$ ), plus a further set of metal species that are not currently in the CLP but are needed by waste classifiers in order to better complete their hazardous waste classifications. The paper defines the methodology used, the limitations and exceptions so that other metal species that are not included in Table 3 can be appraised in the same way.
The paper also provides a worked example showing how a waste classifier can use the lists in Table 3 and guidance in this paper to help optimize both their laboratory testing and utilise other information to move from a precautionary, worst case metal species towards a more reasonable worst case species. The discussion provides examples of the various lines of evidence, such as physical properties like solubility, and extra laboratory tests that can be undertaken to achieve a more reasonable classification.

With the advent of sophisticated waste classification software, that manage both the compounds, their metadata and automates all the calculations and exceptions, the classifier is now able to move rapidly from worst case to more reasonable case metal species and document the lines of evidence for their decisions.

\section{REFERENCES}

AFNOR XP 30-489: 2013. Characterization of waste - Determination of the content of elements and substances in waste (in French). AFNOR, France

Bishop, I. and Gill, T., 2018. Why you shouldn't assume your non-hazardous feedstock is non-hazardous: The forensic analysis of a filter cake produced from the manufacture of firefighting foam from hoof and horn meal. 6th International Conference on Industrial and Hazardous Waste Management, CRETE 2018. Paper available from www.hazwasteonline.com

C\&L 2020. European Chemicals Agency. Classification and Labeling Inventory Database: www.echa.europa.eu/information-on-chemicals/cl-inventory-database.

CL:AIRE 2011. The Definition of Waste: Development Industry Code of Practice, Version 2, published by Published by Contaminated Land: Applications in Real Environments (CL:AIRE), March 2011.

Concawe 2020. Literature Review: Effects-Based Analysis for Soils, Risk Management and Waste Disposal; Report no. 16/20, prepared by Marks, B., Leverett, D. and Bishop, I., August 2020.

CRC 2020. CRC Handbook of chemistry and physics, 101st edition, Editor: Rumble, J.R., CRC Press, July 2020.

EA 2018. Performance Standard for Laboratories undertaking chemical testing of soil. Environment Agency, November 2018, version 5.

ECHA 2017. European Chemicals Agency. Guidance on the application of the CLP criteria, version 5.0, July 2017. ISBN 978-92-9020-0505. Available from https://echa.europa.eu/guidance-documents/ guidance-on-clp.

EEC 1967. Council Directive 67/548/EEC of 27 June 1967 on the approximation of laws, regulations and administrative provisions relating to the classification, packaging and labelling of dangerous substances

EN 12457-2:2002. Characterization of waste - Compliance test for leaching of granular waste materials and sludges - Part 2: One stage batch test at a liquid to solid ratio of $10 \mathrm{l} / \mathrm{kg}$ for materials with particle size below $4 \mathrm{~mm}$ (without or with size reduction). CEN, Belgium.

EN 15192:2007. Characterization of waste and soil - Determination of chromium (VI) in solid materials by alkaline digestion and ion chromatography with spectrophotometric detection. CEN, Belgium.

ESA 2018. A sampling and testing protocol to assess the status of incinerator bottom ash, Environmental Services Association, www. esauk.org, January 2018.

EU 1999. Directive 1999/45/EC of the European Parliament and of the Council of 31 May 1999 concerning the approximation of the laws, regulations and administrative provisions of the Member States relating to the classification, packaging and labelling of dangerous preparations.

EU 2003. Council Decision 2003/33/EC of 19 December 2002 establishing criteria and procedures for the acceptance of waste at landfills pursuant to Article 16 of and Annex II to Directive 1999/31/EC.

EU 2004. Regulation (EC) No 850/2004 of the European Parliament and of the Council of 29 April 2004 on persistent organic pollutants and amending Directive 79/117/EEC. 
EU 2006. Regulation (EC) No 1907/2006 of the European Parliament and of the Council concerning the Registration, Evaluation, Authorisation and Restriction of Chemicals (REACH), establishing a European Chemicals Agency, amending Directive 1999/45/EC and repealing Council Regulation (EEC) No 793/93 and Commission Regulation (EC) No 1488/94 as well as Council Directive 76/769/ EEC and Commission Directives 91/155/EEC, 93/67/EEC, 93/105/ EC and 2000/21/EC.

EU 2008a. Directive 2008/98/EC of the European Parliament and of the Council of 19 November 2008 on waste and repealing certain Directives.

EU 2008b. Regulation (EC) No 1272/2008 of the European Parliament and of the Council of 16 December 2008, on classification, labelling and packaging of substances and mixtures, amending and repealing Directives 67/548/EEC and 1999/45/EC, and amending Regulation (EC) No 1907/2006.

EU 2008c. Regulation (EC) No 440/2008 of 30 May 2008 laying down test methods pursuant to Regulation (EC) No 1907/2006 of the European Parliament and of the Council on the Registration, Evaluation, Authorisation and Restriction of Chemicals (REACH)

EU 2009. Regulation (EC) No 790/2009 of 11 August 2009 amending, for the purposes of its adaptation to technical and scientific progress, Regulation (EC) No 1272/2008 of the European Parliament and of the Council on classification, labelling and packaging of substances and mixtures.

EU 2011. Regulation (EC) No 286/2011 of 10 March 2011 amending, for the purposes of its adaptation to technical and scientific progress, Regulation (EC) No 1272/2008 of the European Parliament and of the Council on classification, labelling and packaging of substances and mixtures.

EU 2014a. Commission Decision 2014/955/EU of 18 December 2014 amending Decision 2000/532/EC on the list of waste pursuant to Directive 2008/98/EC of the European Parliament and of the Council.

EU 2014b. Commission Regulation (EU) No 1357/2014 of 18 December 2014, amending Annex III to Directive 2008/98/EC of the European Parliament and of the Council on waste and repealing certain Directives.

EU 2014c. Commission Regulation (EU) No 1342/2014 of 17 December 2014 amending Regulation (EC) No 850/2004 of the European Parliament and of the Council on persistent organic pollutants as regards Annexes IV and V.

EU 2016. Regulation (EU) 2016/1179 of 19 July 2016 amending, for the purposes of its adaptation to technical and scientific progress, Regulation (EC) No 1272/2008 of the European Parliament and of the Council on classification, labelling and packaging of substances and mixtures.

EU 2017. Regulation (EU) No 2017/997 of 8 June 2017, amending Annex III to Directive 2008/98/EC of the European Parliament and of the Council as regards the hazardous property HP 14 'Ecotoxic'.

EU 2018. European Commission; Commission notice on technical guidance on the classification of waste, 2018/C 124/01.

EU 2020. Regulation (EU) 2020/1182 of 19 May 2020, amending, for the purposes of its adaptation to technical and scientific progress, Part 3 of Annex VI to Regulation (EC) No 1272/2008 of the European Parliament and of the Council on classification, labelling and packaging of substances and mixtures.
GHS 2019. Globally Harmonized System of Classification and Labelling of Chemicals, United Nations Economic Commission for Europe, Revision 8, May 2019.

Hennebert, P., 2019. Hazard classification of waste: Review of available practical methods and tools. Detritus, Volume 07, p 13-28 Sept 2019.

Hennebert, P., Humez, N., Conche, I., Bishop, I. and Rebishung, F., 2016. Assessment of four calculation methods proposed by the EC for waste hazardous property HP 14 'Ecotoxic'. Waste Management Vol. 48, p 24-33.

Hennebert P., Papin A., Padox J-M., Hasebrouck B., 2013. The evaluation of an analytical protocol for the determination of substances in waste for hazard classification. Waste Management Vol. 33, p 1577-1588.

IARC 2020. International Agency for Research on Cancer, World Health Organisation. IARC monographs on the identification of carcinogenic hazards to humans. Accessed 24 July 2020. https://monographs.iarc.fr/list-of-classifications

INERIS 2015. Study Report DRC-15-149793-04619A: Waste Hazardousness Assessment - Proposition of methods (version 2), 15 May 2015.

INERIS 2016. Study Report DRC-16-159393-04351A: Etude comparative des regles de classement des melanges au titre du reglement CLP et des dechets au titre des proprietes de danger HP, 12 November 2016.

Lead REACH Consortium 2015(a). Industry proposed self-classification for lead compounds. Substance grade data sheets accessed 24 July 2020: https://ila-reach.org/our-substances/lead-compounds/.

Lead REACH Consortium 2015(b). Industry proposed self-classification for lead metal. Substance grade data sheets accessed 24 July 2020: https://ila-reach.org/our-substances/lead-metal/.

MAIB 2017. Report on the investigation of the explosion of gas released from a cargo of un-processed incinerator bottom ash on Nortrader at anchorage in Plymouth Sound on 13 January 2017 Marine Accident Investigation Branch, Report No. 26/2017.

Norden 2016. Nordic Council of Ministers. Hazardous waste classification - Amendments to the European Waste Classification regulation - what do they mean and whet are the consequences. Margarete Wahlstron, Jutta Laine-Ylijoki, Ola Wik, Anke Oberender and Ole Hjelmar. ISBN978-92-893-4532-3.

UK 2018. European Union (Withdrawal) Act 2018.

UK 2019. The Chemicals (Health and Safety) and Genetically Modified Organisms (Contained Use) (Amendment etc.) (EU Exit) Regulations 2019

UK 2020. The Chemicals (Health and Safety) and Genetically Modified Organisms (Contained Use) (Amendment etc.) (EU Exit) Regulations 2020

WM3 2018. Waste Classification: Guidance on the classification and assessment of waste (1st Edition v1.1): Technical Guidance WM3. Environment Agency, NIEA, SEPA, Natural Resources Wales. Available from: http://www.gov.uk/government/publications/ waste-classification-technical-guidance.
${ }^{1}$ Cut-off - for a substance with one or more additive hazard statements (see next footnote), the measured concentration can be ignored in the calculations if the measured concentration is below the cut-off concentration.

${ }^{2}$ Additive $(\Sigma)$ means that if two or more substances have the same additive hazard statement, then the concentrations of those substances need to be added together before the sum is compared to the threshold (e.g. H300 Acute Tox. 1 is $\Sigma \geq 0.1 \%$ or $1,000 \mathrm{mg} / \mathrm{kg}$ ). HP 4, HP 5, HP 6 \& HP 8 have one or more additive type hazard statements. HP 14 is also additive but the calculations are more complex. PCDD/PCDF substances require a different additive calculation based on Toxic Equivalency Factors (TEF).

${ }^{3}$ Individual (Ind.) indicates that if any single substance has a concentration that exceeds the threshold then it will trigger the hazardous property (e.g. $\mathrm{H} 350$ Carc $1 \mathrm{~A}$ is Ind. $\geq 0.1 \%$ or $1,000 \mathrm{mg} / \mathrm{kg}$ )

${ }^{4}$ In 2017, a vessel carrying a cargo of un-processed IBA suffered a gas explosion following the accidental release of fresh water into the vessel's hold and subsequently, hydrogen gas leaking into an electrical switch box (MAIB 2017). IBA has the potential to release hydrogen where finely divided aluminium is present and water is added. Although the quantities of hydrogen produced are likely to be less than the threshold for classification of the IBA as hazardous, under HP 3 (fifth indent) $(\mathrm{H} 260, \mathrm{H} 261)$, it is considered best practice for both IBA hazard and risk assessments to consider the potential for of the ash to generate hydrogen gas, test if necessary and take appropriate precautions to minimise the risk of fire or explosion. This includes the handling and storage arrangements for buildings, transport vessels or containers having adequate ventilation to ensure that any gas is dispersed safely.

${ }^{5} \mathrm{M}$ factors or multiplication factors are scaling factors $(M=1,10,100$, up to $1,000,000$ for some pesticides) that are applicable to products (but not to wastes). They can reduce the hazardous threshold for a given hazard statement e.g. $\mathrm{H} 410$ Aquatic chronic 2; $\mathrm{M}=100$ would reduce the $0.25 \%$ $(2,500 \mathrm{mg} / \mathrm{kg})$ threshold to $0.0025 \%(25 \mathrm{mg} / \mathrm{kg})$

${ }^{6}$ Species - there may be more than one species of a particular metal in a waste; for example an incinerator ash may comprise zinc oxide and other zinc minerals such as zinc silicates. Unless more specialised testing and modelling is undertaken, most classifiers of mixtures assume that a given metal is only present as a single species or phase.

In the England and Wales, larger construction projects can follow the 
CL:AIRE Definition of Waste: Code of Practice (CL:AIRE 2011). A Materials Management Plan defines the different types of soils on the site (including contaminated soils) and which soils can be re-used and which have to leave site as a waste and hence require classification. The guidance is derived from Article 2 of the WFD.

${ }^{8}$ A lab tells us that we have $\mathbf{3 6 0 . 5} \mathrm{mg} / \mathrm{kg}$ of zinc in our waste which we assume is in the form of zinc chromate. How much zinc chromate do we have? Molecular formula: $\mathrm{ZnCrO}$

Atomic weights for each element (www.ptable.com): $\mathrm{Zn}=65.38$; $\mathrm{Cr}=51.996 ; 0=15.999$

Molecular Weight (MW): $(1 \times 65.38)+(1 \times 51.996)+(4 \times 15.999)=181.372$

$\mathrm{g} / \mathrm{mole}$

Conversion Factor (CF): $181.372 /(1$ x 65.38) = $\mathbf{2 . 7 7 4}$

Therefore the concentration of zinc chromate is: $\mathbf{3 6 0 . 5} \times \mathbf{2 . 7 7 4}=\mathbf{1 , 0 0 0}$ $\mathrm{mg} / \mathrm{kg}$

${ }^{9}$ Minimum entry - these are entries in CLP Table 3 that have a hazard statement's category code marked with a single *

${ }^{10} \mathrm{Note} \mathrm{H}$ - in the older European chemical legislation (Dangerous Substanc- es Directive (EEC 1967)), the note $\mathrm{H}$ was published in CLP Table 3 to indicate a known, incomplete entry.

${ }^{11}$ ICP-OES - Inductively Coupled Plasma - Optical Emission Spectroscopy is a technique that uses a plasma as a source and uses the optical emission spectra to identify and quantify the elements present.

${ }_{12}$ For $1,000 \mathrm{mg} / \mathrm{kg}$ zinc chromate $\mathrm{ZnCrO}$, how much chromium $(\mathrm{VI})$ is present? Atomic weights for each element (www.ptable.com): $\mathrm{Zn}=65.38$; $\mathrm{Cr}=51.996 ; \mathrm{O}=15.999$

Molecular Weight (MW): $181.372 \mathrm{~g} / \mathrm{mole}$

Amount chromium(VI): 51.996/181.372 *1,000 = $286.682 \mathrm{mg} / \mathrm{kg}$

13 "significantly less" - perhaps $10 \%$ to $20 \%$ less - because in most mixtures you can never expect a good stoichiometric match, a judgement has to be made when trying to undertake some element of a mass balance. This is due to a combination of a) the accuracy of lab testing (for soils under MCERTS (EA, 2018) measurement precision is $7.5 \%-15 \%$ and bias $10 \%$ $30 \%$, depending on determinand), b) sampling density and c) the presence of other (un-investigated) metals (and/or metal species) and organic compounds in the waste.

${ }^{14}$ Note that: $(\# 9 \times \# 10) / 10,000=\# 5$ for each species in Table 3 